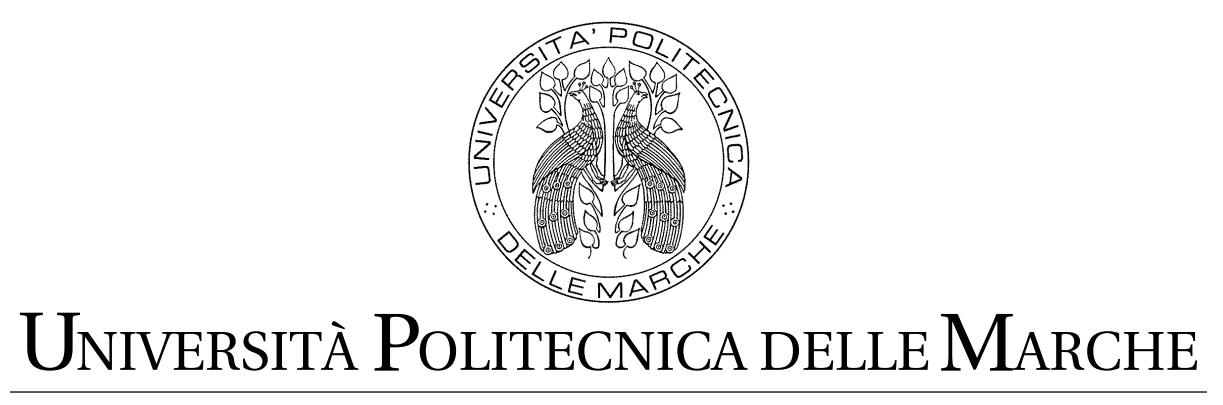

Dipartimento di Scienze Economiche e Sociali

GENDER AND THE EFFECT OF WORKING HOURS ON FIRM-SPONSORED TRAINING

Matteo Picchio And Jan C. van OURS

QUADERNO DI RICERCA n. 413

ISSN: 2279-9575

November 2015 
Comitato scientifico:

Marco Gallegati

Stefano Staffolani

Alessandro Sterlacchini

Alberto Zazzaro

Collana curata da:

Massimo Tamberi 
JEL Class.: $\quad$ C33, C35, J24, M51, M53

Keywords: Part-time employment; working hours; firm-sponsored training; gender; human capital

Indirizzo: Matteo Picchio. Corresponding author. Department of Economics and Social Sciences, Marche Polytechnic University, Piazzale Martelli 8, 60121 Ancona, Italy. Tel: +39220 7176. E-mail: m.picchio@univpm.it. CentER, Tilburg University, The Netherlands. IZA, Germany.

Jan C. van Ours. Department of Economics, Tilburg University, PO Box 90153, 5000 LE Tilburg, The Netherlands. Tel: +33 13466 2880. E-mail: vanours @uvt.nl. University of Melbourne, Australia. CentER, Tilburg University, The Netherlands. CEPR, United Kingdom; CESifo, Germany. IZA, Germany. 



\title{
Gender and the Effect of Working Hours on Firm-Sponsored Training*
}

\author{
Matteo Picchio and Jan C. van Ours
}

\section{Introduction}

Part-time work is often confused with flexible labor and inferior labor standards. However, the main difference between part-time jobs and flexible jobs is that part-time jobs provide flexibility to the employer and job protection to the workers while flexible jobs provide flexibility to the employer and insecurity to the worker. Part-time jobs provide flexibility to the employer in terms of allocating hours of work across the workweek or workday to meet peaks in market demand. Part-time jobs provide flexibility to the worker in terms of allocating hours of work across the workweek to better coordinate work and personal activities. A part-timer can have a temporary contract or a permanent contract.

There are quite substantial cross-country differences in the nature of part-time work. There is a negative cross-country relationship between the share of women working parttime and the share of involuntary part-timers. This negative relationship may seem counterintuitive, but it is not. The quality of the part-time job is the mediating variable. Although typically part-timers enjoy less favorable employment conditions these are not embedded in part-time jobs. The higher the share of part-timers the stronger is their bargaining position. If the share of part-timers increases, the quality of part-time employment increases as well (see also Boeri and van Ours, 2013). Therefore, whether or not a part-time job is an inferior job also depends on whether part-time jobs are a rare phenomenon.

It is not the case that part-time jobs offer intrinsically less job stability to the in-

${ }^{*}$ We thank CentERdata of Tilburg University for providing us with the LISS (Longitudinal Internet Studies for the Social sciences) panel data on which we based our empirical analysis. The LISS panel data were collected by CentERdata through its MESS project funded by the Netherlands Organization for Scientific Research. We wish also to thank the participants to the AIEL conference in Cagliari (September 2015), to the ZEW Research Seminar (October 2015), Elizabeth J. Casabianca and two anonymous reviewers for their comments and suggestions. 
dividual worker although in many countries part-time work and job instability are correlated. Blázquez Cuesta and Moral Carcedo (2014) study labor market transitions in Denmark, the Netherlands, France, Italy and Spain, using data from the European Community Household Panel (1995-2001). They find that part-timers are more likely to make a transition to non-employment than full-timers in four of the five countries. However, in the Netherlands transition rates from employment to non-employment are very similar for part-timers and full-timers. So, also in terms of job stability, the position of part-timers is clearly country-specific.

Part-time work is not equally distributed across the working age population. Salladarré and Hlaimi (2014) study the determinants of female part-time employment in 23 European countries using Round 5 of the European Social Survey (2010-11). They distinguish between long part-time work (20-29 hours per week) and short part-time work (less than 20 hours per week) finding that cross-country the two types of part-time work tend to be complementary. Furthermore, they show that short part-time jobs are more common among women in the youngest and the oldest age groups, among those suffering from a slight injury, those with a larger number of children and those with less education and training.

Part-time work is not only associated with job instability but also with lower pay and fewer opportunities to make a career. Connolly and Gregory (2009) for example study part-time pay penalties of British women from a long-term perspective. For this, they analyze the British New Earnings Survey Panel Dataset using data from a 27-year unbalanced panel which records the earnings, working hours and occupations. They find that part-time work in itself has a small pay penalty, but part-time work causes women to follow a different career path with lower earnings throughout the remainder of their working life. It is this lower earnings trajectory which damages earnings of women rather than the part-time work itself. Women who want to work fewer hours are often forced to achieve this by changing employers and accept a downgraded job. The authors also find that the earnings damage of working part-time for a while is not removed if later on women go back to full-time jobs. The authors also mention a possible explanation for the direct part-time pay penalty. Part-time jobs are more expensive for employers because of the fixed labor costs which are spread out over fewer working hours. If this is not balanced by reduced labor costs related to organizational flexibility to meet fluctuations in demand hourly wages have to go down in order for employers to make it profitable to create part-time jobs. ${ }^{1}$

\footnotetext{
${ }^{1}$ Connolly and Gregory (2009) conclude that the socially and personally efficient outcome would be
} 
Whether indeed part-time workers are less productive than full-time workers is not clear and may depend on the nature of the job. Künn-Nelen et al. (2013) is a rare example of a study on the productivity of part-time workers. They analyze data for the Dutch pharmacy sector finding that firms with a large part-time employment share are more productive than firms with a large share of full-time workers. The main reason is that firms with a large share of part-timers are able to allocate their workers more efficiently across working days. The authors find that part-time workers are not more productive than full-time workers at the individual level, i.e. in the hours they work they are equally productive. The allocation efficiency related to part-time workers has three sources. First, pharmacies are open around 50 hours a week whereas the full-time working week counts 36 hours. Therefore, allocating part-timers across the workweek increases efficiency. Second, part-timers can be used such that the pharmacies can remain open during lunch breaks of full-timers. Finally, part-timers may be used during parts of the day when there are peaks in consumer demand.

One of the reasons suggested for part-time workers to have less opportunities to make a career is that they are less likely to receive employer-sponsored training (Bassanini et al., 2007; Blundell et al., 1996). Therefore, their productivity does not increase as much as it would have increased otherwise.

Our paper is on the extent to which part-time workers in the Netherlands receive firmsponsored training. In our analysis we make a distinction between part-time working women and men. Hours of work are a determinant of the working time volume of the match between workers and firms and, thereby, of the propensity of firms to invest in training of their employees. Given that firm-sponsored training seems to positively affect wages, productivity and employment (Dostie, 2015; Picchio and van Ours, 2013) and that women are more likely to work part-time, it is important to assess whether the amount of working hours could affect firm-sponsored training and contribute to explain gender differences in the Dutch labor market.

As far as we know, Backes-Gellner et al. (2014) is the only study that investigates gender-specific differences in the relationship between part-time employment and firmsponsored training. Analyzing Swiss data the authors find that female workers are less likely to receive firm-sponsored training than male workers. However, there is also a part-time effect with part-timers being less likely to receive training than full-timers. This part-time training gap appears to be gender-specific. Whereas women working part-time

part-time jobs as reduced hours versions of full-time jobs, avoiding occupational downgrading. As we discuss in more detail in Section 2, this is the situation in the Netherlands. 
have a similar training incidence as full-time working women, part-time working men are less likely to be trained than full-time working men. The authors argue that their findings may be due to stereotyping where employers think that men who work part-time signal a lower attachment to their job.

We present an empirical analysis of the relationship between hours of work and firmsponsored training. We show that the negative effect of part-time work on the probability to receive employer-sponsored training holds for male workers but not for female workers. Whereas male part-time workers are less likely to receive training, part-time working women are as likely to receive training as full-time working women. We cannot rule out the possibility of gender-working hours specific monopsony power but speculate that the gender-specific effect of working hours on training has to do with gender-specific stereotyping. In the Netherlands, for women it is common to work part-time. More than half of the prime age female employees work part-time. Among younger and older female workers the share of part-timers is even higher. On the contrary for males, working part-time is a rare event. Except for younger and older men, the share of part-timers is below $10 \%$. So, part-time working men are a rare breed. Therefore, because of social norms, men working part-time could send a different signal to their employer than women working part-time. This might generate a different propensity of firms to sponsor training of male part-timers than female part-timers. Nevertheless, this different propensity may also have to do with firms having more monopsony power over part-time working women than they have of part-time working men. This would allow them to reap some of the productivity-related benefits of the training of part-time working women.

Our contribution to the literature is twofold. First, as far as we know, our paper is the first one to use panel data to study whether there are gender-specific differences in the relationship between part-time work and training. Backes-Gellner et al. (2014) for example use cross-sectional data and therefore their identification strategy relies on observed characteristics. Our panel data allow us to take unobserved individual characteristics into account and exploit the longitudinal dimension to further relax the strict exogeneity assumption implied by fixed effects estimators. Second, we study data from a country with a high share of part-time workers. This allows us to study the relationship between parttime work and training in great detail.

Our paper is set up as follows. Section 2 describes the institutional set-up of the Dutch labor market with respect to the use of part-time work. Section 3 describes the data and the sample used in the empirical investigation. Section 4 formalizes the econometric model and clarifies the identification strategy. The estimation results are presented and 
discussed in Section 5. Finally, Section 6 concludes.

\section{Part-time employment in the Netherlands}

As shown in the top graph of Figure 1, among prime age employed female workers in the Netherlands, the share of part-timers is very high. It is about $55 \%$ and quite stable over the time period 2000-2013. The OECD average for female workers is a little over $20 \%$. For male prime age workers, the share of part-timers in the Netherlands is not very different from the OECD average and far below the share of female part-timers. Over the period 2000-2013, there is a slight increase but the shares are still substantially below $10 \%$.

The bottom graph of Figure 1 shows the prevalence of part-time work by age category for the Netherlands and the average of the OECD countries. The patterns are very similar but the levels are substantially different. Prevalence of part-time work is highest among youngsters and older workers. Whereas in the age group 15-19 years the prevalence of part-time work is more than $90 \%$ among Dutch female workers, it is 'only' about $60 \%$ on average for female workers in OECD countries. Among male workers aged 15-19, the incidence of part-time work in the Netherlands is about $80 \%$ whereas on average in OECD countries it is about $40 \%$.

Although part-time work makes it possible for young mothers to combine work and care, part-time jobs are not exclusively for young mothers. In the Netherlands, currently almost half of the part-time working women are over 40 years of age and no longer have young children. About $40 \%$ of women with part-time jobs are mothers of young children who work part-time because they either prefer this or have no choice but to provide childcare themselves. A little over $10 \%$ of women with part-time jobs are mothers with older children (Booth and van Ours, 2013).

One of the reasons for part-time work being popular in the Netherlands is that parttime jobs are not inferior to full-time jobs in terms of the nature of the work and social security arrangements such as unemployment insurance, disability benefits, pension benefits and minimum wage. By and large, part-time jobs only differ in terms of working hours from full-time jobs. Originally, in the 1950s part-time jobs were introduced for married women in response to shortages of young female staff (Portegijs et al., 2006). When part-time jobs became more popular, changes in labor regulations were introduced which further stimulated their popularity. ${ }^{2}$ In 1993 , for example, the statutory exemption

\footnotetext{
${ }^{2}$ According to Portegijs et al. (2006), the Netherlands and Sweden have a policy aiming to make parttime work more attractive to workers unlike countries like Spain, the UK, Germany and France, where
} 
Figure 1: PART-TIME EMPlOYMENT IN THE NETHERLANDS AND OECD A: Prime Age (25-54); 2000-2013

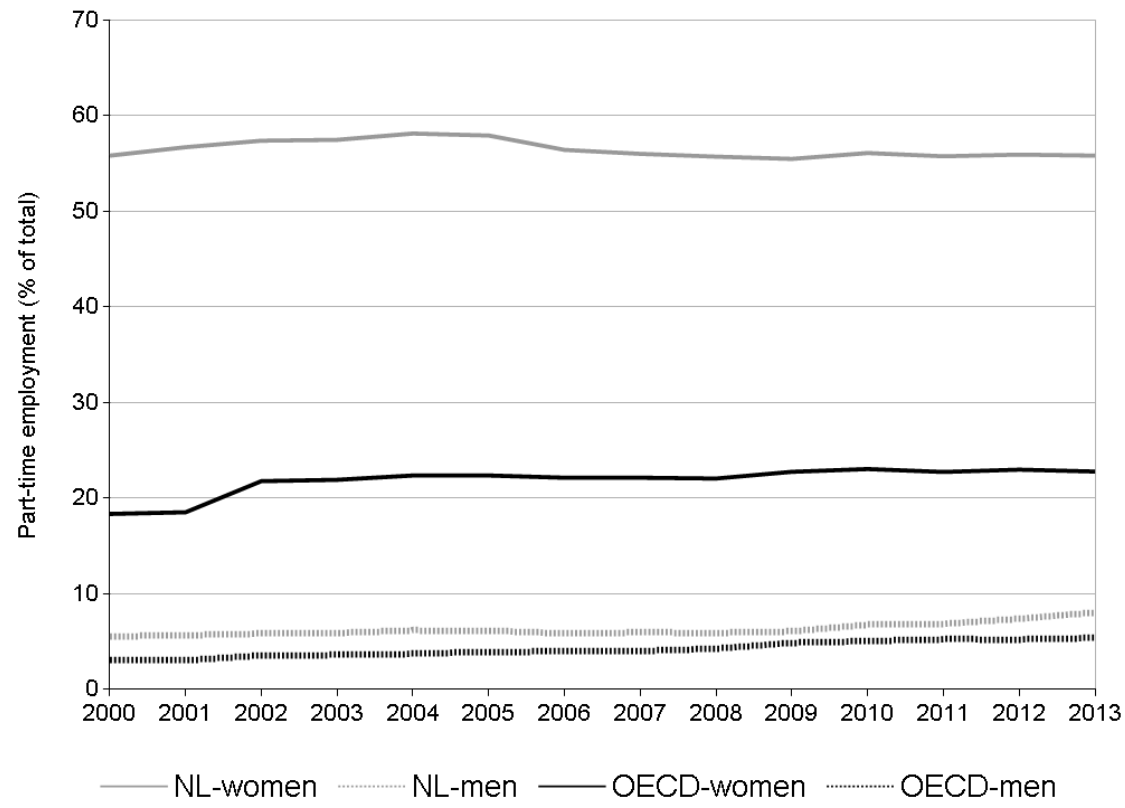

B: BY AGE GROUP; 2013

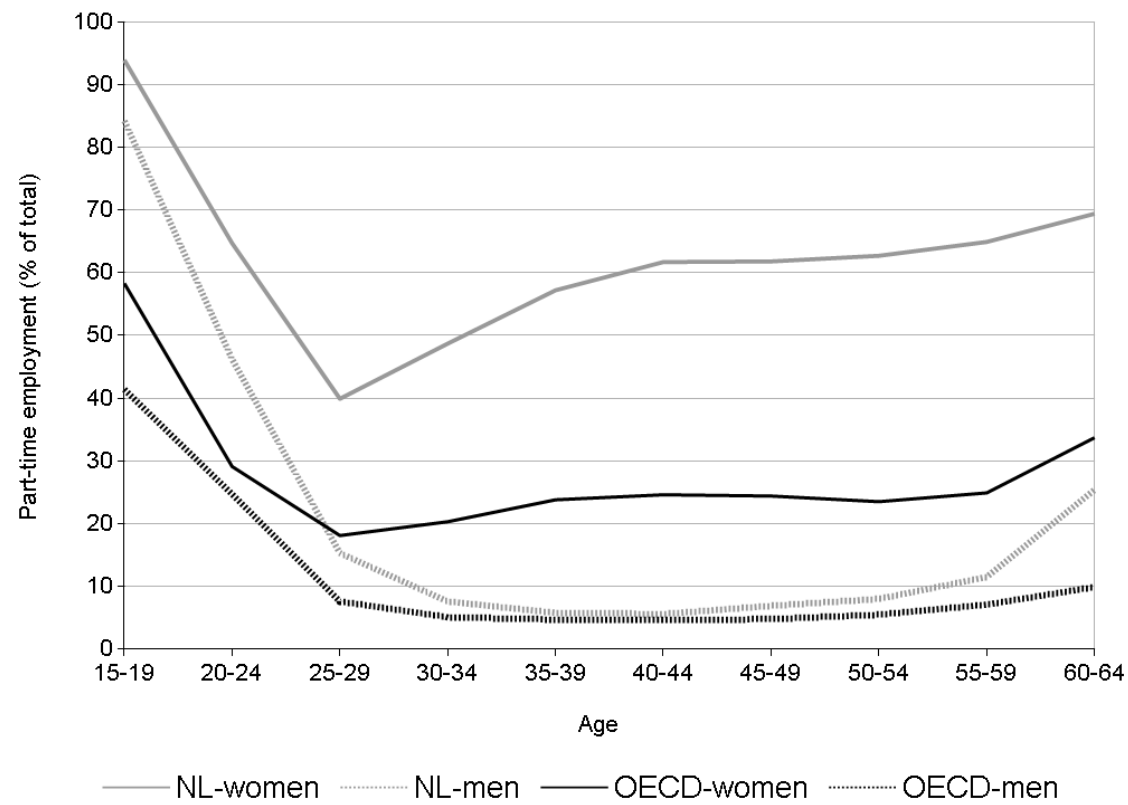

Source: OECD Labor Force Statistics; a part-time job has a working week of less than 30 hours. 
of jobs of less than one-third of the normal working week from application of the legal minimum wage and related social security entitlements were abolished. So part-timers have the same social security arrangements and minimum wage as full-timers. In 2000, a right to part-time work law was introduced.

In the meantime, part-time jobs are so popular among Dutch women that on average many women who work in "large" part-time jobs prefer to work shorter hours. According to Portegijs et al. (2006), a part-time job between 20 and 27 hours a week is the preferred choice of many women. ${ }^{3}$ Indeed, using data on preferred working hours, Booth and van Ours (2013) calculated the number of hours at which there is an equilibrium in the sense that the number of individuals wanting to work more is as large as the number of individuals wanting to work less. For women, the equilibrium number of weekly working hours is about 21, while for men, it is about 32 .

Part-time jobs are not only popular among Dutch women. Also some employers have a preference for part-time labor as it provides them with organizational flexibility i.e. it allows them to vary labor input if market demand fluctuates over the week like, in retailing (Euwals and Hogerbrugge, 2006). Bosch et al. (2010) find that the incidence of part-time work has increased over successive generations at the expense of full-time and small parttime jobs. As a result, the average working hours of working women remained stable over successive cohorts. Bosch and van der Klaauw (2012) analyze the effects of a 2001 tax reform which made work much more financially attractive for women with a high-income partner. Nevertheless, they find that women actually reduced their working hours slightly in response to receiving a higher after-tax hourly wage.

\section{Data Description}

The data used in this paper are from a new Dutch panel, the Longitudinal Internet Studies for the Social Sciences (LISS) panel. The LISS panel is collected and administered by CentERdata of Tilburg University. A representative sample of households is drawn from a population register by Statistics Netherlands and asked to join the panel by Internet interviewing. Households are provided with a computer and/or an Internet connection if

governments aim to make part-time work more attractive for employers.

${ }^{3}$ There is no uniform definition of part-time work. In OECD-statistics, a part-time job is a job less than 30 hours per week (van Bastelaer et al., 1997). Statistics Netherlands defines jobs of 12-19 hours per week as small part-time jobs and job of 20-34 hours per week as large part-time jobs. From 35 hours per week onwards, jobs are full-time jobs. 
they do not have one. ${ }^{4}$ The LISS panel is made up of several study units. Different study units can have different timings and frequency over the year in data collection. Some background information on general characteristics, like demography, family composition, education, labor market position and earnings, is measured on a monthly basis, from November 2007 until October 2015 (at the time of writing). Ten core studies are instead carried out once a year and cover a wide set of topics, like health, religion and ethnicity, social integration and leisure, family and household, work and schooling, personality, politics and economic situation. ${ }^{5}$ For this study we exploit the monthly information of the background variables and the core study on work and schooling, which was carried out mostly in April from 2008 until 2014. ${ }^{6}$ The core study on work and education comprises a broad range of questions about labor market participation, job characteristics, pensions, schooling and training. People are asked whether they attended work-related training courses in the last 12 months and, if so, who sponsored the training course. People are also asked whether they are at work at the moment of the interview and if they are employees, the type of contract if employed and the type of non-employment status if not working.

Between 5,358 and 6,951 individuals were interviewed each year for the core study on work and schooling between 2008 and 2014, resulting in a total of 42,538 records, corresponding to 11,995 different individuals. We focus on employees who are older than 25 and younger than 55 years of age. We drop employees with on-call jobs and those who, according to their employment contract, have less than 10 or more than 60 weekly working hours. We keep only workers who are in the core study on work and schooling for at least two consecutive years: this restriction is due to the fact that we will estimate a model in first differences. After the application of these sample selection criteria, we are left with an unbalanced panel of 3,117 workers for a total of 12,904 records over the years from 2008 until $2014 .^{7}$ Table 1 clarifies the structure of the resulting panel dataset.

Table 2 reports relative and absolute frequencies of workers who have received firmsponsored training in the last 12 months by gender and by contractual working hours.

\footnotetext{
${ }^{4}$ See Knoef and de Vos (2009) for an evaluation of the representativeness of the LISS panel and Scherpenzeel $(2011,2010)$ and Scherpenzeel and Das (2010) for methodological notes on the design of the LISS panel.

${ }^{5}$ See http://www.lissdata.nl/dataarchive/study_units/view/1 for the full list of studies of the LISS panel.

${ }^{6}$ About $5.5 \%$ of the 2008 interviews were conducted in July, whilst between $1.6 \%$ and $9.1 \%$ of the interviews between 2009 and 2014 were collected in May.

${ }^{7}$ When we keep employees between 25 and 55 years of age, the sample shrinks to 16,071 observations (5,377 individuals). By selecting those with weekly working hours between 10 and 60 , we are left with 15,537 records $(5,196$ different workers). Finally, removing those who are not in the sample for at least two consecutive years restricts the sample to 12,904 observations (3,117 workers).
} 
TABLE 1: THE STRUCTURE OF THE UNBALANCED PANEL

\begin{tabular}{|c|c|c|c|c|}
\hline \multirow[b]{2}{*}{ Years of observation } & \multicolumn{2}{|c|}{ Individual records } & \multicolumn{2}{|c|}{ Total records } \\
\hline & $\begin{array}{r}\text { Absolute } \\
\text { frequencies }\end{array}$ & $\begin{array}{r}\text { Relative } \\
\text { frequencies }\end{array}$ & $\begin{array}{r}\text { Absolute } \\
\text { frequencies }\end{array}$ & $\begin{array}{r}\text { Relative } \\
\text { frequencies }\end{array}$ \\
\hline $2008-2014$ & 611 & .196 & 4,277 & .331 \\
\hline 2008-2013 & 158 & .051 & 948 & .074 \\
\hline $2008-2010$ & 314 & .101 & 924 & .073 \\
\hline 2008-2012 & 178 & .057 & 890 & .069 \\
\hline 2008-2009 & 441 & .141 & 882 & .068 \\
\hline 2012-2014 & 273 & .088 & 819 & .064 \\
\hline 2008-2011 & 179 & .057 & 716 & .056 \\
\hline 2010-2014 & 126 & .040 & 630 & .049 \\
\hline 2011-2014 & 60 & .019 & 240 & .019 \\
\hline 2009-2014 & 39 & .013 & 234 & .018 \\
\hline 2010-2011 & 115 & .037 & 230 & .018 \\
\hline 2012-2013 & 114 & .037 & 228 & .018 \\
\hline 2008-2009/2011-2014 & 38 & .012 & 228 & .018 \\
\hline 2010-2013 & 51 & .016 & 204 & .016 \\
\hline 2010-2012 & 56 & .018 & 168 & .013 \\
\hline 2013-2014 & 78 & .025 & 156 & .012 \\
\hline 2008-2010/2012-2014 & 24 & .008 & 144 & .011 \\
\hline 2008-2011/2013-2014 & 23 & .007 & 138 & .011 \\
\hline 2009-2010 & 56 & .018 & 112 & .009 \\
\hline 2008-2010/2012-2013 & 21 & .007 & 105 & .008 \\
\hline Further 16 trajectories & 162 & .052 & 613 & .047 \\
\hline Total & $N=3,117$ & 1.000 & $N T=12,904$ & 1.000 \\
\hline
\end{tabular}

Almost 53\% of the employees in our sample are women. Women working part-time ${ }^{8}$ are much more likely to receive firm-sponsored training than men $(30.9 \%$ for women against $24.8 \%$ for men).

Figure 2 depicts by gender the share of workers receiving firm-sponsored training by classes of contractual weekly working hours. Both male and female part-timers have a lower probability of receiving firm-sponsored training but the relationship is much steeper for men. Whereas for full-time working men and women the incidence of firm-sponsored training is not very different, in the 10-20 working hours category the share of women receiving firm-sponsored training is about $25 \%$ while for men it is only about $12 \%$.

Figure 3 displays the histogram estimator of the density of the contractual working hours by gender, showing that in the Netherlands men are concentrated between 36-40 hours of work per week, whilst women are more scattered with the mode of the female distribution at 24 weekly working hours. Table 3 reports summary statistics of the variables used in the econometric analysis by gender. More than one third of the employees attended at least one training course sponsored by the employer in the preceding 12

\footnotetext{
${ }^{8} \mathrm{~A}$ worker is a part-timer if (s)he works strictly less than 30 hours per week.
} 
TABLE 2: FREQUENCIES OF WORKERS RECEIVING

FIRM-SPONSORED TRAINING BY PART-TIME AND GENDER

(ABSOLUTE FREQUENCIES IN PARENTHESES)

\begin{tabular}{lccc}
\hline \hline & \multicolumn{2}{c}{ Firm-sponsored training } \\
& No & Yes & Total \\
\hline Full-time & Men & \\
Part-time & $0.629(3,685)$ & $0.371(2,177)$ & $1.000(5,862)$ \\
Total & $0.752(200)$ & $0.248(66)$ & $1.000(266)$ \\
& $0.634(3,885)$ & $0.366(2,243)$ & $1.000(6,128)$ \\
Full-time & Women & \\
Part-time & $0.584(1,773)$ & $0.416(1,262)$ & $1.000(3,035)$ \\
Total & $0.691(2,585)$ & $0.309(1,156)$ & $1.000(3,741)$ \\
& $0.643(4,358)$ & $0.357(2,418)$ & $1.000(6,766)$ \\
\hline
\end{tabular}

months and almost $7.5 \%$ of men and $9.5 \%$ of women have a temporary job (either fixedterm job or temporary work agency job). ${ }^{9}$ The average number of contractual working hours is much larger for men: 37.6 hours against 27.3 hours of women. The average age is about 42 years with 11 years of job tenure for men and 10 years for women. More than $47 \%$ have at least a higher secondary degree. On average each household has 3 members and 1.2 children living in the household. More than $19 \%$ of the people are single and about $40 \%$ live in a very or extremely urban area. Women are more likely than men to work in a public or semi-public company and to work in the sector of education, health or welfare.

\section{Econometric Modeling}

We are primarily interested in understanding whether there are gender differences in the way in which working hours might affect employees' probability of receiving firmsponsored training. We will therefore specify and estimate a linear equation for the probability of receiving firm-sponsored training as a function of contractual working time and a set of controls capturing individual heterogeneity. The variable for the contractual working hours is potentially endogenous for several reasons. First, there might be self-selection issues determined by unobserved heterogeneity. Workers having contracts for longer weekly working hours might have different motivations, skills and attachment to the labor market than employees working a smaller number of hours. Second, there might be feedback effects, i.e. shocks in the training indicator affecting the future level

\footnotetext{
${ }^{9}$ We do not include in the sample on-call workers as they are deemed to have structurally different jobs, given the production technology of the sectors where they are employed.
} 
FIGURE 2: PERCENTAGE OF WORKERS RECEIVING FIRM-SPONSORED TRAINING BY CLASSES OF CONTRACTUAL WEEKLY WORKING HOURS AND GENDER

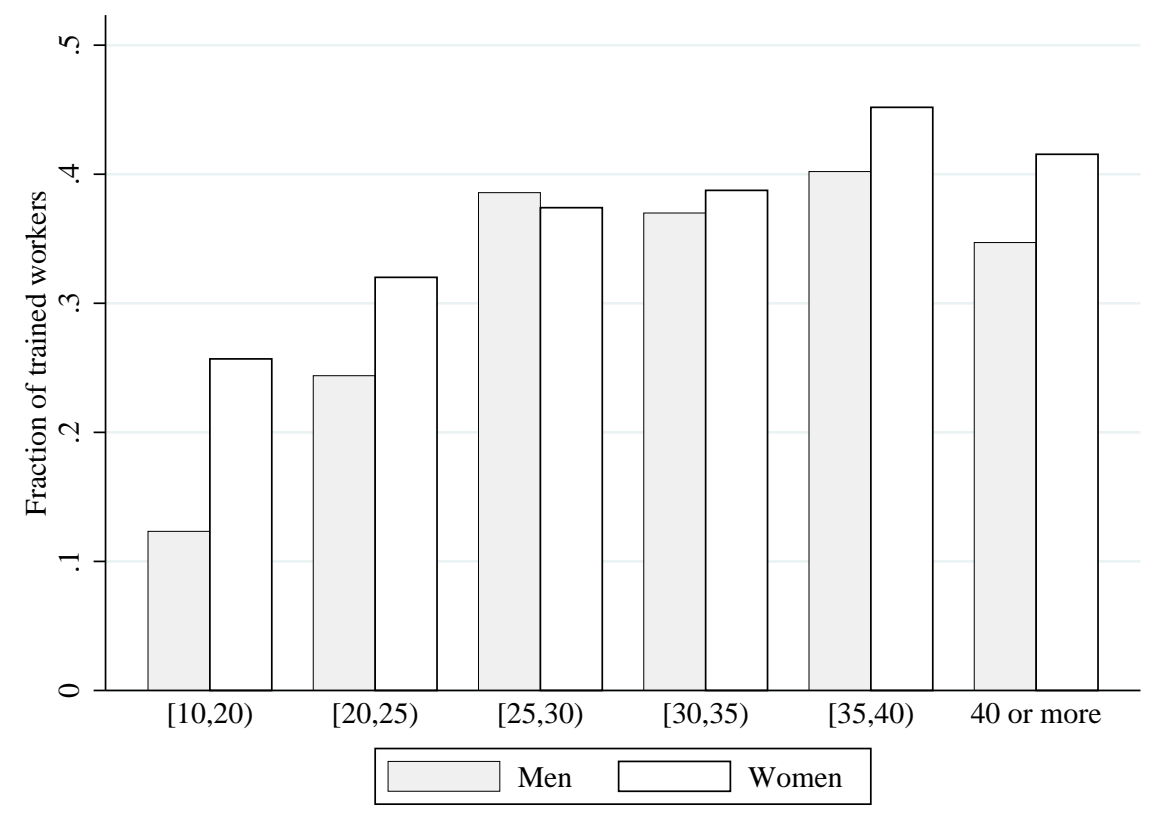

FIGURE 3: DISTRIBUTION OF CONTRACTUAL WORKING HOURS BY GENDER
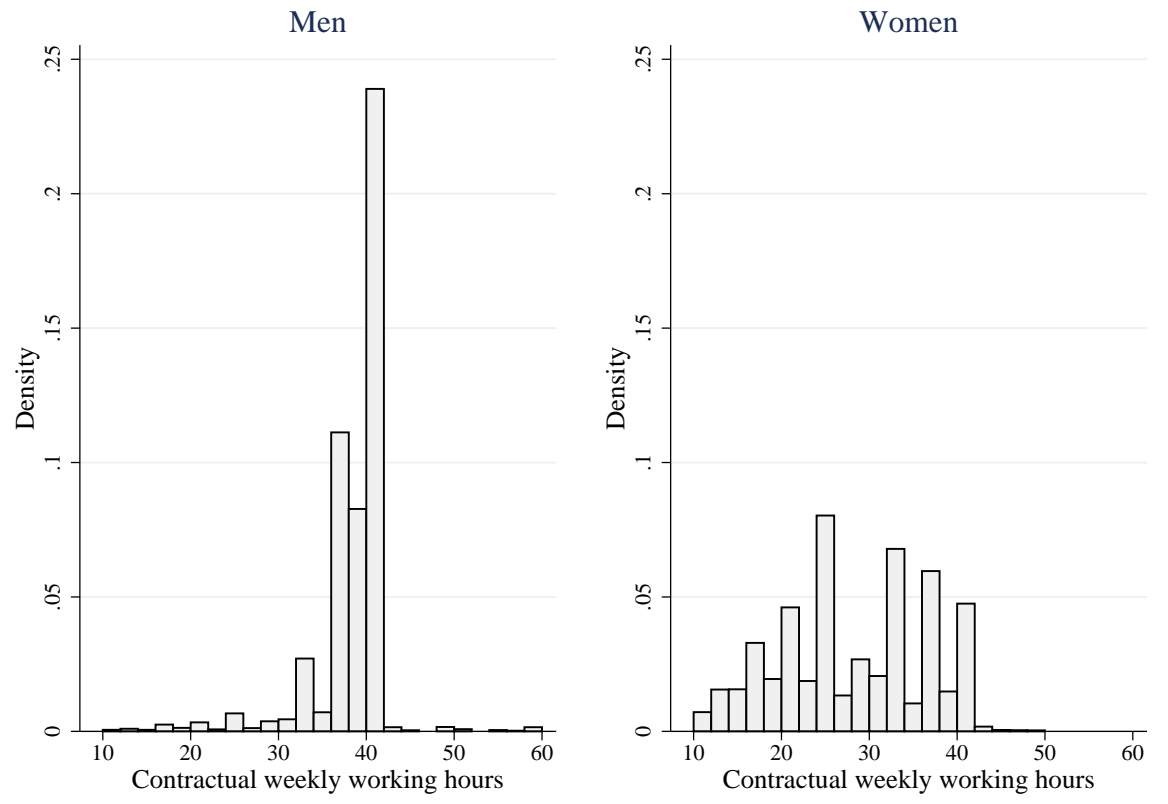
TABLE 3: SUMMARY STATISTICS OF THE POOLED SAMPLE BY GENDER

\begin{tabular}{|c|c|c|c|c|}
\hline & \multicolumn{2}{|c|}{ Men } & \multicolumn{2}{|c|}{ Women } \\
\hline & Mean & Std. Dev. & Mean & Std. Dev. \\
\hline Firm-sponsored training & 0.366 & 0.482 & 0.357 & 0.479 \\
\hline Contractual working hours & 37.563 & 4.491 & 27.338 & 8.308 \\
\hline Part-time job $^{(a)}$ & 0.043 & 0.204 & 0.552 & 0.497 \\
\hline Age in years & 42.06 & 8.14 & 41.28 & 8.46 \\
\hline \multicolumn{5}{|l|}{ Education } \\
\hline Primary & 0.032 & 0.177 & 0.032 & 0.175 \\
\hline Intermediate secondary (vmbo/mbo) & 0.489 & 0.500 & 0.483 & 0.500 \\
\hline Higher secondary (havo/hbo) & 0.365 & 0.481 & 0.382 & 0.486 \\
\hline University or more & 0.113 & 0.317 & 0.101 & 0.302 \\
\hline Head of the household & 0.875 & 0.331 & 0.343 & 0.475 \\
\hline Single & 0.198 & 0.398 & 0.222 & 0.416 \\
\hline Urban area & 0.401 & 0.490 & 0.410 & 0.492 \\
\hline Temporary job & 0.075 & 0.264 & 0.095 & 0.293 \\
\hline Job tenure in 1000 days & 3.994 & 3,356 & 3.598 & 3.053 \\
\hline Public employment & 0.279 & 0.448 & 0.470 & 0.499 \\
\hline \multicolumn{5}{|l|}{ Sector } \\
\hline Agriculture/Mining/Manufacturing & 0.304 & 0.460 & 0.073 & 0.260 \\
\hline Retail trade/Transport/Communication & 0.138 & 0.345 & 0.105 & 0.307 \\
\hline Finance & 0.059 & 0.235 & 0.051 & 0.220 \\
\hline Services & 0.195 & 0.396 & 0.146 & 0.353 \\
\hline Education/Health/Welfare & 0.118 & 0.323 & 0.452 & 0.498 \\
\hline Other sectors & 0.186 & 0.389 & 0.173 & 0.378 \\
\hline \multicolumn{5}{|l|}{ Occupation } \\
\hline High skilled white collar ${ }^{(b)}$ & 0.208 & 0.406 & 0.097 & 0.297 \\
\hline Low skilled white collar ${ }^{(c)}$ & 0.512 & 0.500 & 0.790 & 0.407 \\
\hline High skilled blue collar ${ }^{(\mathrm{d})}$ & 0.140 & 0.347 & 0.016 & 0.124 \\
\hline Low skilled blue collar ${ }^{(\mathrm{e})}$ & 0.139 & 0.346 & 0.097 & 0.296 \\
\hline \multicolumn{5}{|l|}{ Firm size (number of employees) } \\
\hline$(0-10]$ employees & 0.144 & 0.351 & 0.203 & 0.402 \\
\hline$(10-20]$ employees & 0.111 & 0.314 & 0.138 & 0.345 \\
\hline$(20-100]$ employees & 0.309 & 0.462 & 0.278 & 0.448 \\
\hline More than 100 employees & 0.337 & 0.473 & 0.236 & 0.425 \\
\hline Number of employees unknown & 0.098 & 0.297 & 0.145 & 0.352 \\
\hline \# of household components & 3.006 & 1.376 & 2.973 & 1.289 \\
\hline \# of kids in the household & 1.180 & 1.164 & 1.180 & 1.101 \\
\hline \multicolumn{5}{|l|}{ Year } \\
\hline 2008 & 0.161 & 0.367 & 0.156 & 0.363 \\
\hline 2009 & 0.170 & 0.375 & 0.169 & 0.375 \\
\hline 2010 & 0.155 & 0.362 & 0.157 & 0.364 \\
\hline 2011 & 0.134 & 0.341 & 0.139 & 0.346 \\
\hline 2012 & 0.144 & 0.352 & 0.145 & 0.352 \\
\hline 2013 & 0.131 & 0.338 & 0.133 & 0.340 \\
\hline 2014 & 0.104 & 0.305 & 0.100 & 0.300 \\
\hline \# of observations (\# of individuals) & \multicolumn{2}{|c|}{$6,128(1,468)$} & \multicolumn{2}{|c|}{$6,776(1,649)$} \\
\hline
\end{tabular}

(a) The full-time indicator is based on contractual weekly working hours. We define as fulltimers those employees with 30 or more contractual working hours per week.

(b) High skilled white collar workers have a higher academic profession (e.g. architect, physician, scholar, engineer) or a higher supervisory profession (e.g. manager, director, supervisory civil servant).

(c) Low skilled white collar workers have an intermediate academic profession (e.g. teacher, nurse, social worker, policy assistant) or an intermediate supervisory or commercial profession (e.g. head representative, department manager, shopkeeper) or other mental work.

(d) High skilled blue collar workers have a skilled and supervisory manual work (e.g. electrician).

(e) Low skilled blue collar workers have a semi-skilled (e.g. driver) or an unskilled manual work (e.g. cleaner). 
of working time. For instance, workers with a positive transitory shock in the probability of receiving training might have the opportunity to accumulate human capital, get a promotion, higher wages and, thereby, different working time choices. Alternatively, if there is a negative shock in the probability of receiving firm-sponsored training, employees might lose the possibility to get a promotion and new responsibilities that might be linked to longer working hours. Lastly, the choice of the working hours might send to the employer different signals depending on employee's gender, as well as all the other covariates might affect the probability of receiving firm-sponsored training differently for men and women. Hence, the econometric analysis will be conducted separately for men and women.

Denote by $y_{i t}$ the dummy indicator equal to 1 if employee $i$ received firm-sponsored training in the 12 months before time $t$ and 0 otherwise. The conditional probability that $y_{i t}$ is equal to 1 is specified, for $t=1, \ldots, T$ and $i=1, \ldots, N$, as

$$
\mathrm{P}\left(y_{i t}=1 \mid h_{i t}, \mathbf{x}_{i t}, c_{i}\right)=\mathrm{E}\left(y_{i t} \mid h_{i t}, \mathbf{x}_{i t}, c_{i}\right)=\delta h_{i t}+\mathbf{x}_{i t}^{\prime} \boldsymbol{\beta}+c_{i},
$$

where $h_{i t}$ is the contractual working hours, $\mathbf{x}_{i t}$ is a $1 \times K$ vector of observed individual characteristics and $c_{i}$ is time-invariant unobserved heterogeneity. The model in Equation (1), if expressed in the error equation form, is

$$
y_{i t}=\delta h_{i t}+\mathbf{x}_{i t}^{\prime} \boldsymbol{\beta}+c_{i}+u_{i t}
$$

where $u_{i t}$ is an idiosyncratic error term. The coefficient of primary interest is $\delta$, which is the marginal effect of increasing weekly working hours on the probability of receiving firm-sponsored training. If $c_{i}$ were not correlated to $\mathbf{h}_{i}$, where $\mathbf{h}_{i} \equiv\left[h_{i 1}, h_{i 2}, \ldots, h_{i T}\right]$, and $\mathbf{h}_{i}$ were strictly exogenous, i.e. $\mathrm{E}\left(u_{i t} \mid \mathbf{h}_{i}, \mathbf{x}_{i}\right)=0$ for all $t=1, \ldots, T$, then the Ordinary Least Square (OLS) estimator of Equation (2), ignoring the presence of $c_{i}$, would return unbiased and consistent estimates of $\delta$. However, the unobserved heterogeneity term $c_{i}$ might be correlated to the observables. For example, more career oriented employees might be more willing to receive firm-sponsored training and be more likely to work more hours per week. If $\operatorname{Cov}\left(\mathbf{h}_{i}, c_{i}\right) \neq 0$, we cannot consistently estimate Equation (2) by OLS simply ignoring $c_{i}$.

By taking the first difference of both sides of Equation (2), we get rid of the fixed effects $c_{i}$ yielding

$$
\Delta y_{i t}=\delta \Delta h_{i t}+\Delta \mathbf{x}_{i t}^{\prime} \boldsymbol{\beta}+\Delta u_{i t} .
$$


Under the strict exogeneity assumption, the OLS estimator yields unbiased estimates of the coefficients in Equation (3). However, as mentioned above, there might be good reasons to believe in the presence of feedback effects from $y_{i t}$ to $h_{i r}$, with $r>t$, i.e. in shocks in the training indicator affecting future levels of working time. If so, the strict exogeneity assumption would fail. We relax the strict exogeneity assumption and replace it by the sequential moment restriction (Chamberlain, 1992): $\mathrm{E}\left(u_{i t} \mid h_{i t}, h_{i t-1}, \ldots, h_{i 1}, \mathbf{x}_{i}, c_{i}\right)=0$ for all $t=1, \ldots, T$. Hence, we allow arbitrary correlation between $u_{i t}$ and future values of the working hours indicator $\left(h_{t+1}, \ldots, h_{t+T}\right)$. In other words, as pointed out by Wooldridge (2010), we assume that once we condition on $\left(h_{i t}, \mathbf{x}_{i}, c_{i}\right)$, no past values of $h_{i t}$ affects the probability of receiving firm-sponsored training at time $t$, meaning that, conditional on the current level of working hours (and the other observables and unobservables), we assume that the employers do not exploit information about past levels of contractual working hours (or their variations) when planning how to allocate training resources among the employees. Henceforth, under the sequential moment restriction, the longitudinal dimension of our dataset provides a valid instrument to take into account the potential endogeneity of $\Delta h_{i t}$ in Equation (3) because of feedback effects. The sequential moment restriction indeed implies that $h_{i t-1}$ is not correlated to $\Delta u_{i t}$. Moreover, $h_{i t-1}$ is very likely be a strong predictor of the endogenous variable $\Delta h_{i t}$. We will therefore use the Two Stage Least Square (2SLS) estimator with $h_{i t-1}$ as an instrument for $\Delta h_{i t}$ to consistently estimate Equation (3) in the presence of feedback effects from participation in firm-sponsored training to weekly working hours.

A further problem which might arise and invalidate the sequential moment restriction and the validity of $h_{i t-1}$ as a valid instrument for $\Delta h_{i t}$ is reverse causality. At each wave, we have information about training incidence in the 12 months before the interview and the contractual working hours at the time of the interview. We do not know therefore when the contractual working time was set and whether the contractual working time is predetermined with respect to training incidence. If $h_{i t}$ is not predetermined with respect to $y_{i t}$, then it might be that training participation in the 12 months before time $t$ could affect the contractual working time declared at time $t$. therefore, in order to avoid biases due to reverse causality, we also estimate Equation (3) under a less strict version of the sequential moment restriction: $\mathrm{E}\left(u_{i t} \mid h_{i t-1}, \ldots, h_{i 1}, \mathbf{x}_{i}, c_{i}\right)=0$. We use therefore $h_{i t-2}$, instead of $h_{i t-1}$, as an instrument for $\Delta h_{i t}$. By doing so, we allow working hours to be contemporaneously correlated to the error term.

We will use two different measures of contractual working hours $h_{i t}$ : the first one counts the number of contractual weekly working hours; the second one is a dichotomous 
TABLE 4: WITHIN INDIVIDUAL TIME VARIATION IN THE WEEKLY

CONTRACTUAL WORKING HOURS AND PART-TIME INDICATOR

\begin{tabular}{lrrrr}
\hline \hline & \multicolumn{2}{c}{ Men } & \multicolumn{2}{c}{ Women } \\
Absolute & $\begin{array}{r}\text { Relative } \\
\text { frequencies }\end{array}$ & $\begin{array}{r}\text { Absolute } \\
\text { frequencies }\end{array}$ & $\begin{array}{r}\text { Relative } \\
\text { frequencies }\end{array}$ \\
\hline Variation in working hours $\Delta h_{i t}=h_{i t}-h_{i t-1}$ & & & & \\
$\quad$ Less than -20 & 4 & 0.001 & 5 & 0.001 \\
{$[-20,10)$} & 10 & 0.002 & 57 & 0.011 \\
{$[-10,0)$} & 128 & 0.028 & 336 & 0.067 \\
0 & 4,246 & 0.930 & 4,216 & 0.838 \\
$(0,10]$ & 157 & 0.034 & 380 & 0.075 \\
$(10,20]$ & 16 & 0.004 & 37 & 0.007 \\
More than 20 & 4 & 0.001 & 3 & 0.001 \\
Variation in part-time indicator $\Delta p t_{i t}=p t_{i t}-p t_{i t-1}$ & & & & \\
-1 & 27 & 0.006 & 101 & 0.020 \\
0 & 4,513 & 0.989 & 4,816 & 0.957 \\
1 & 25 & 0.005 & 117 & 0.023 \\
\hline Total & 4,565 & \multicolumn{3}{c}{5,034} \\
\hline
\end{tabular}

indicator equal to one if the worker is a part-timer (strictly less than 30 weekly working hours) and zero otherwise.

When the equation for the probability of receiving firm-sponsored training is taken in first differences, identification of the effect of working hours is based on its time variation at individual level. Table 4 reports the distribution of the within individual time variation of the working time variables by gender, since we will estimate the baseline model separately for men and women. If we consider the part-time indicator as a measure of working hours, then we have little variation over time at individual level to identify the effect: only $1.1 \%$ of men and $4.3 \%$ of women experience a change in the part-time indicator. The contractual weekly working hours show instead more variation over time, with $7 \%$ of the male observations and $16.2 \%$ of female observations varying the contractual weekly working hours from one year to the next one.

\section{Empirical findings}

\subsection{Baseline models}

Table 5 reports the estimation results in level and first differences of the linear probability model in Equation (1), separately for men (top panel) and women (bottom panel), with contractual weekly working hours as the measure of working hours. Table 6 reports the estimation results of the same model, but using the part-time indicator as variable of 
primary interest.

The OLS estimator of Equation (2) ignoring $c_{i}$ returns quite similar results for men and women. An increase by one hour in the contractual weekly working hours is associated to a significant increase by 0.6 percentage points in the probability of receiving firm-sponsored training, both for men and women. Moving from full-time to part-time employment significantly reduces the probability of firm-sponsored training by 9.4 percentage points for men and 7.4 percentage points for women. The positive correlation between working time and the probability of receiving firm-sponsored training is theoretically expected. If the labor market is not perfect and is affected by a certain degree of monopsony power, employers can momentarily extract rents from the trained employees (Acemoglu, 1997), the employer might be more willing to provide full-timers with training, since training costs will be recouped in a briefer period and, therefore, with a smaller probability of a loss in case of the worker quitting the position. However, there might be other reasons explaining the positive association between working time and firmsponsored training. First, the contractual weekly working hours might be a signal used by the employers to approximate workers' job and labor market attachment: the higher the propensity of a worker to work for a larger number of hours, the higher the attachment to the labor force and/or to her job. This implies a lower probability of quitting and, therefore, higher chances for the firm to recoup the training investment from a worker who is willing to accept a contract with a larger number of working hours. Second, the positive correlation could be explained by omitted variables that jointly determine both working hours and the propensity of receiving firm-sponsored training: for example, more able workers might be more likely to receive firm-sponsored training because (s)he is expected to learn a lot from a training course and, at the same time, might be more (or less) likely to work more hours since higher abilities might be reflected in higher wage rates. A priori it is difficult to predict the direction of the omitted variables bias, since it depends on the sign of the correlation between the unobservables, working hours and training chances.

The OLS estimator of Equation (3), after first-differencing the dataset, returns an estimated coefficient of working hours variable which is cleaned by the confounding factors due to workers' unobserved heterogeneity. Interestingly, a gender difference in the impact of working hours on the probability of receiving firm-sponsored training arises: whilst for men working one more hour in a week significantly increases by 1.1 percentage points the training chances, for women the effect is nil $(+0.1$ percentage points $)$ and not significantly different from zero; while for men working part-time reduces the probability of firm-sponsored training by 12.8 percentage points, for women the effect of working 
TABLE 5: ESTIMATION RESULTS OF THE MODEL FOR FIRM-SPONSORED TRAINING IN LEVELS AND FIRST DIFFERENCES BY GENDER (CONTRACTUAL WEEKLY WORKING HOURS)

\begin{tabular}{|c|c|c|c|c|c|c|c|c|c|c|c|c|}
\hline \multirow[b]{3}{*}{ Variables } & \multirow{2}{*}{\multicolumn{3}{|c|}{$\begin{array}{c}\text { Levels } \\
\text { OLS }\end{array}$}} & \multirow{2}{*}{\multicolumn{3}{|c|}{ First-difference }} & \multirow{2}{*}{\multicolumn{3}{|c|}{$\begin{array}{c}\text { First-difference } \\
2 S L S \text {, instrument } h_{i t-1}\end{array}$}} & \multirow{2}{*}{\multicolumn{3}{|c|}{$\begin{array}{c}\text { First-difference } \\
\text { 2SLS, instrument } h_{i t-2}\end{array}$}} \\
\hline & & & & & & & & & & & & \\
\hline & \multirow[t]{2}{*}{ Coeff. } & & S.E. & Coeff. & & S.E. & \multicolumn{3}{|c|}{$\begin{array}{l}\text { 2SLS, instrument } h_{i t-1} \\
\text { Coeff. }\end{array}$} & \multirow[t]{2}{*}{ Coeff. } & \multicolumn{2}{|r|}{ S.E } \\
\hline \multicolumn{11}{|l|}{ a) Men } & & \\
\hline Contractual weekly working hours & 0.00550 & $* * *$ & 0.00187 & 0.01075 & $* * *$ & 0.00342 & 0.02803 & $* * *$ & 0.00989 & 0.04666 & * & 0.02795 \\
\hline$($ Age-25)/10 & -0.02693 & & 0.04251 & - & & - & - & & - & - & & - \\
\hline$(\text { Age- } 25)^{2} / 100$ & -0.00296 & & 0.01326 & 0.00312 & & 0.03600 & 0.01975 & & 0.03707 & 0.11431 & $* *$ & 0.05372 \\
\hline \multicolumn{13}{|l|}{ Education-Reference: Primary } \\
\hline Interm. Secondary & 0.00427 & & 0.04625 & - & & - & - & & - & - & & - \\
\hline Higher secondary & 0.02828 & & 0.04918 & - & & - & - & & - & - & & - \\
\hline University or more & 0.02191 & & 0.05630 & - & & - & - & & - & - & & - \\
\hline Head of the household & 0.03605 & & 0.02412 & -0.05108 & & 0.05730 & -0.04523 & & 0.05687 & -0.04176 & & 0.07823 \\
\hline Single & -0.03622 & * & 0.02105 & -0.07530 & & 0.05123 & -0.08032 & & 0.05100 & -0.07034 & & 0.06181 \\
\hline Urban area & -0.03536 & ** & 0.01753 & 0.04724 & & 0.08530 & 0.04811 & & 0.08560 & -0.03114 & & 0.12943 \\
\hline Temporary contract & -0.07283 & ** & 0.02902 & -0.01822 & & 0.04683 & -0.01173 & & 0.04704 & 0.07057 & & 0.06155 \\
\hline Job tenure in days/100 & -0.00025 & & 0.00081 & 0.00451 & $* * *$ & 0.00172 & 0.00493 & $* * *$ & 0.00172 & 0.00587 & $* * *$ & 0.00223 \\
\hline$(\text { Job tenure in days } / 100)^{2}$ & -0.00000 & & 0.00001 & -0.00006 & $* * *$ & 0.00002 & -0.00006 & $* * *$ & 0.00002 & -0.00007 & $* * *$ & 0.00003 \\
\hline Public employment & 0.06082 & ** & 0.02544 & 0.07440 & & 0.07544 & 0.09240 & & 0.07594 & -0.12171 & & 0.10750 \\
\hline Occupation indicators - Reference: Higl & skilled whit & collar $n$ & rker & & & & & & & & & \\
\hline Low skilled white collar & -0.03690 & & 0.02483 & -0.09673 & & 0.07230 & -0.08861 & & 0.07223 & -0.10680 & & 0.13272 \\
\hline High skilled blue collar & 0.02721 & & 0.03498 & -0.01217 & & 0.13460 & -0.01640 & & 0.13287 & -0.15569 & & 0.26303 \\
\hline Low skilled blue collar & -0.05236 & & 0.03542 & -0.00073 & & 0.11254 & -0.01253 & & 0.11126 & -0.05497 & & 0.23270 \\
\hline Constant & 0.17481 & * & 0.09733 & -0.03289 & & 0.02148 & -0.03919 & * & 0.02174 & -0.06840 & $* *$ & 0.02842 \\
\hline \# of observations $N T(N)$ & & $28(1,4$ & & & $65(1,4$ & & & $65(1,46$ & & & $02(1,0$ & \\
\hline$R^{2}$ & & 0.064 & & & 0.011 & & & - & & & - & \\
\hline F-test of excluded instruments & & - & & & - & & & 46.47 & & & 11.07 & \\
\hline Hausman test of endogeneity & & - & & & - & & & 1467)=3 & & & 1080) $=$ & \\
\hline & & - & & & - & & & alue $=0$. & & & alue $=0$ & \\
\hline Hansen $J$ statistics if $h_{i t-1}$ and & & _- & & & _ & & & - & & & $(1)=2$. & \\
\hline$h_{i t-2}$ are jointly used as instruments & & - & & & - & & & - & & & alue $=0$ & \\
\hline Sample selection test: $p$-value & & 0.502 & & & 0.479 & & & 0.487 & & & 0.397 & \\
\hline b) Women & & & & & & & & & & & & \\
\hline Contractual weekly working hours & 0.00579 & $* * *$ & 0.00099 & 0.00148 & & 0.00279 & 0.01146 & & 0.00890 & 0.01485 & & 0.01513 \\
\hline$($ Age-25)/10 & -0.08946 & $* *$ & 0.03637 & - & & - & - & & - & - & & - \\
\hline$(\text { Age- } 25)^{2} / 100$ & 0.01575 & & 0.01100 & 0.02707 & & 0.03229 & 0.01649 & & 0.03314 & 0.06513 & & 0.04575 \\
\hline Education-Reference: Primary & & & & & & & & & & & & \\
\hline Interm. Secondary & -0.04265 & & 0.04008 & - & & - & - & & - & - & & - \\
\hline Higher secondary & 0.01602 & & 0.04127 & - & & - & - & & - & - & & - \\
\hline University or more & 0.05682 & & 0.04865 & - & & - & - & & - & - & & - \\
\hline Head of the household & -0.00094 & & 0.02355 & 0.03443 & & 0.05149 & 0.03043 & & 0.05115 & 0.03652 & & 0.05604 \\
\hline Single & -0.03156 & & 0.02516 & -0.09979 & * & 0.05853 & -0.10376 & $*$ & 0.05868 & -0.12098 & & 0.07491 \\
\hline Urban area & -0.04285 & $* * *$ & 0.01533 & 0.09056 & & 0.07522 & 0.08531 & & 0.07500 & 0.10553 & & 0.10180 \\
\hline Temporary contract & -0.05918 & $* *$ & 0.02484 & -0.00878 & & 0.03579 & -0.00626 & & 0.03605 & 0.00372 & & 0.05323 \\
\hline Job tenure in days $/ 100$ & 0.00071 & & 0.00084 & 0.00032 & & 0.00157 & 0.00034 & & 0.00159 & -0.00040 & & 0.00198 \\
\hline$(\text { Job tenure in days } / 100)^{2}$ & -0.00000 & & 0.00001 & -0.00001 & & 0.00002 & -0.00001 & & 0.00002 & -0.00001 & & 0.00003 \\
\hline Public employment & 0.04651 & $* *$ & 0.01954 & 0.05992 & & 0.06163 & 0.06703 & & 0.06319 & -0.02547 & & 0.09486 \\
\hline Occupation indicators - Reference: $\mathrm{Hi}$ & skilled whit & collar n & & & & & & & & & & \\
\hline Low skilled white collar & -0.04817 & & 0.03098 & 0.21565 & $* * * *$ & 0.07638 & 0.23903 & $* * *$ & 0.07788 & 0.24801 & *** & 0.11791 \\
\hline High skilled blue collar & -0.05449 & & 0.06894 & -0.05989 & & 0.18270 & -0.03822 & & 0.17925 & -0.16588 & & 0.24225 \\
\hline Low skilled blue collar & -0.16198 & $* * *$ & 0.03686 & 0.15462 & & 0.09815 & 0.17919 & * & 0.09805 & 0.03870 & & 0.17432 \\
\hline Constant & 0.31103 & $* * *$ & 0.07486 & -0.04002 & ** & 0.01921 & -0.03658 & $*$ & 0.01912 & -0.09378 & $* * * *$ & 0.02691 \\
\hline \# of observations $N T(N)$ & & $76(1,6$ & & & $34(1,6$ & & & $34(1,6$ & & & $92(1,1$ & \\
\hline$R^{2}$ & & 0.098 & & & 0.007 & & & - & & & - & \\
\hline F-test of excluded instruments & & - & & & - & & & 142.66 & & & 65.28 & \\
\hline Hausman test of endogeneity & & - & & & - & & $\mathrm{F}(1$ & $1648)=$ & & & 1158)= & \\
\hline & & - & & & - & & & alue $=0$. & & & alue $=0$ & \\
\hline Hansen $J$ statistics if $h_{i t-1}$ and & & - & & & - & & & - & & & $(1)=2$. & \\
\hline$h_{i t-2}$ are jointly used as instruments & & - & & & - & & & - & & & alue $=0$ & \\
\hline Sample selection test: $p$-value & & 0.161 & & & 0.322 & & & 0.320 & & & 0.850 & \\
\hline
\end{tabular}
Sample selection test: $p$-value

Notes: * Significant at $10 \%$ level; ** significant at $5 \%$ level; *** significant at $1 \%$ level. The standard errors are robust to heteroskedasticity and serial correlation. Year, sectoral and firm size dummies are included in the model specification but their estimated coefficients are not reported. "2SLS, instrument $h_{i t-1}$ " refers to the model in which we use the 2SLS estimator with $h_{i t-1}$ as a valid instrument for $\Delta h_{i t}$ to allow feedback effects from participation in firm-sponsored training to working hours. "2SLS, instrument $h_{i t-2 \text { " refers to }}$ the model in which we use the 2SLS estimator with $h_{i t-2}$ as a valid instrument for $\Delta h_{i t}$ to further avoid reverse causality. 


\section{TABLE 6: ESTIMATION RESULTS OF THE MODEL FOR FIRM-SPONSORED TRAINING IN LEVELS AND FIRST DIFFERENCES BY GENDER (PART-TIME INDICATOR)}

\begin{tabular}{|c|c|c|c|c|c|c|c|c|c|c|c|c|}
\hline \multirow[b]{3}{*}{ Variables } & \multicolumn{3}{|c|}{$\begin{array}{l}\text { Levels } \\
\text { OIS }\end{array}$} & \multicolumn{3}{|c|}{ First-difference } & & \multirow{2}{*}{\multicolumn{3}{|c|}{$\begin{array}{c}\text { First-difference } \\
\text { 2SLS, instrument } h_{i t-2}\end{array}$}} \\
\hline & \multicolumn{3}{|c|}{ OLS } & \multicolumn{3}{|c|}{ OLS } & & & & & & \\
\hline & Coeff. & & S.E. & Coeff. & & S.E. & \multicolumn{3}{|c|}{$\begin{array}{l}\text { 2SLS, instrument } h_{i t-1} \\
\text { Coeff. }\end{array}$} & \multirow{2}{*}{ Coeff. } & \multicolumn{2}{|c|}{ S.E. } \\
\hline \multicolumn{12}{|l|}{ a) Men } & \\
\hline Working part-time & -0.09410 & ** & 0.03789 & -0.12804 & *** & 0.06312 & -0.52062 & $* * *$ & 0.17022 & -0.70021 & & 0.54980 \\
\hline$($ Age-25)/10 & -0.02525 & & 0.04256 & - & & - & - & & - & - & & - \\
\hline$(\text { Age- } 25)^{2} / 100$ & -0.00356 & & 0.01328 & -0.00222 & & 0.03606 & 0.01312 & & 0.03648 & 0.10221 & * & 0.05363 \\
\hline \multicolumn{13}{|l|}{ Education-Reference: Primary } \\
\hline Interm. Secondary & 0.00506 & & 0.04642 & - & & - & - & & - & - & & - \\
\hline Higher secondary & 0.02808 & & 0.04935 & - & & - & - & & - & - & & - \\
\hline University or more & 0.02237 & & 0.05651 & - & & - & - & & - & - & & - \\
\hline Head of the household & 0.03898 & & 0.02395 & -0.05110 & & 0.05742 & -0.03999 & & 0.05743 & -0.03722 & & 0.07912 \\
\hline Single & -0.03659 & $*$ & 0.02114 & -0.07548 & & 0.05130 & -0.08561 & $*$ & 0.05148 & -0.07440 & & 0.06327 \\
\hline Urban area & -0.03573 & ** & 0.01748 & 0.04583 & & 0.08502 & 0.04318 & & 0.08455 & -0.03993 & & 0.12859 \\
\hline Temporary contract & -0.07460 & ** & 0.02905 & -0.02169 & & 0.04713 & -0.01994 & & 0.04834 & 0.06303 & & 0.06655 \\
\hline Job tenure in days $/ 100$ & -0.00026 & & 0.00081 & 0.00441 & *** & 0.00173 & 0.00492 & $* * *$ & 0.00172 & 0.00567 & *** & 0.00225 \\
\hline$(\text { Job tenure in days } / 100)^{2}$ & -0.00000 & & 0.00001 & -0.00005 & $* * *$ & 0.00002 & -0.00006 & $* * *$ & 0.00002 & -0.00007 & $* * *$ & 0.00003 \\
\hline Public employment & 0.05492 & ** & 0.02534 & 0.06531 & & 0.07593 & 0.07180 & & 0.07554 & -0.16250 & & 0.10869 \\
\hline \multicolumn{13}{|c|}{ Occupation indicators - Reference: High-skilled white collar worker } \\
\hline Low skilled white collar & -0.03887 & & 0.02487 & -0.09738 & & 0.07328 & -0.08385 & & 0.07444 & -0.10367 & & 0.14265 \\
\hline High skilled blue collar & 0.02386 & & 0.03507 & -0.01024 & & 0.13547 & -0.01238 & & 0.13442 & -0.17870 & & 0.27122 \\
\hline Low skilled blue collar & -0.05500 & & 0.03549 & 0.00320 & & 0.11308 & -0.00726 & & 0.11231 & -0.05480 & & 0.25187 \\
\hline Constant & 0.38823 & $* * *$ & 0.06877 & -0.03045 & & 0.02147 & -0.03499 & & 0.02165 & -0.06032 & ** & 0.02785 \\
\hline \# of observations $N T(N)$ & & $28(1,4$ & & & $65(1,4$ & & & $65(1,46)$ & & & $02(1,0$ & \\
\hline$R^{2}$ & & 0.063 & & & 0.010 & & & - & & & - & \\
\hline F-test of excluded instruments & & - & & & - & & & 29.36 & & & 7.70 & \\
\hline Hausman test of endogeneity & & - & & & - & & & 1467)=7 $=7$ & & & 1080)= & \\
\hline & & - & & & - & & & alue $=0$. & & & alue $=0$ & \\
\hline Hansen $J$ statistics if $h_{i t-1}$ and & & - & & & - & & & - & & & $(1)=1$. & \\
\hline$h_{i t-2}$ are jointly used as instruments & & - & & & - & & & - & & & alue $=0$ & \\
\hline Sample selection test: $p$-value & & 0.481 & & & 0.456 & & & 0.403 & & & 0.456 & \\
\hline b) Women & & & & & & & & & & & & \\
\hline Working part-time & -0.07404 & $* * *$ & 0.01636 & 0.03376 & & 0.03976 & -0.04493 & & 0.12498 & -0.24565 & & 0.23275 \\
\hline$($ Age-25)/10 & -0.10274 & $* * *$ & 0.03614 & - & & - & - & & - & - & & - \\
\hline$(\text { Age- } 25)^{2} / 100$ & 0.01906 & * & 0.01097 & 0.03104 & & 0.03246 & 0.02544 & & 0.03317 & 0.06286 & & 0.04722 \\
\hline Education-Reference: Primary & & & & & & & & & & & & \\
\hline Interm. Secondary & -0.04673 & & 0.04022 & - & & - & - & & - & - & & - \\
\hline Higher secondary & 0.01736 & & 0.04146 & - & & - & - & & - & - & & - \\
\hline University or more & 0.06103 & & 0.04862 & - & & - & - & & - & - & & - \\
\hline Head of the household & 0.00584 & & 0.02325 & 0.03655 & & 0.05162 & 0.03300 & & 0.05149 & 0.02768 & & 0.05754 \\
\hline Single & -0.02996 & & 0.02505 & -0.09908 & * & 0.05846 & -0.09938 & $*$ & 0.05841 & -0.11022 & & 0.07531 \\
\hline Urban area & -0.04153 & $* * *$ & 0.01537 & 0.09201 & & 0.07537 & 0.09045 & & 0.07484 & 0.10422 & & 0.10098 \\
\hline Temporary contract & -0.06014 & ** & 0.02500 & -0.00908 & & 0.03570 & -0.00926 & & 0.03571 & 0.00333 & & 0.05310 \\
\hline Job tenure in days $/ 100$ & 0.00076 & & 0.00084 & 0.00030 & & 0.00157 & 0.00034 & & 0.00157 & -0.00048 & & 0.00200 \\
\hline$(\text { Job tenure in days } / 100)^{2}$ & -0.00000 & & 0.00001 & -0.00001 & & 0.00002 & -0.00001 & & 0.00002 & -0.00001 & & 0.00003 \\
\hline Public employment & 0.04342 & ** & 0.01957 & 0.05790 & & 0.06120 & 0.06016 & & 0.06178 & -0.02716 & & 0.09583 \\
\hline Occupation indicator & skilled whit & collar $n$ & & & & & & & & & & \\
\hline Low skilled white collar & -0.05418 & $*$ & 0.03072 & 0.20800 & $* * *$ & 0.07630 & 0.21776 & **** & 0.07761 & 0.23877 & *** & 0.11671 \\
\hline High skilled blue collar & -0.05976 & & 0.06789 & -0.06825 & & 0.18324 & -0.05624 & & 0.18282 & -0.16060 & & 0.24128 \\
\hline Low skilled blue collar & -0.17975 & $* * *$ & 0.03615 & 0.14556 & & 0.09837 & 0.15819 & & 0.09935 & 0.03844 & & 0.17727 \\
\hline Constant & 0.52973 & $* * *$ & 0.06403 & -0.04165 & ** & 0.01933 & -0.03905 & ** & 0.01949 & -0.09397 & **** & 0.02703 \\
\hline \# of observations $N T(N)$ & & $76(1,6$ & & & $34(1,6$ & & & $34(1,64$ & & & $92(1,1$ & \\
\hline$R^{2}$ & & 0.096 & & & 0.008 & & & - & & & - & \\
\hline F-test of excluded instruments & & - & & & - & & & 183.93 & & & 83.44 & \\
\hline Hausman test of endogeneity & & - & & & - & & & 1648) $=$ & & & 1158) $=$ & \\
\hline & & - & & & - & & & alue $=0$ & & & alue $=0$ & \\
\hline Hansen $J$ statistics if $h_{i t-1}$ and & & - & & & - & & & - & & & $(1)=3$. & \\
\hline$h_{i t-2}$ are jointly used as instruments & & - & & & - & & & - & & & alue $=0$ & \\
\hline Sample selection test: $p$-value & & 0.238 & & & 0.324 & & & 0.324 & & & 0.403 & \\
\hline
\end{tabular}

Notes: * Significant at $10 \%$ level; ** significant at $5 \%$ level; $* * *$ significant at $1 \%$ level. The standard errors are robust to heteroskedasticity and serial correlation. Year, sectoral an firm size dummies are included in the model specification but their estimated coefficients are not reported. "2SLS, instrument $h_{i t-1}$ " refers to the model in which we use the 2 SLS estimator with $h_{i t-1}$ as a valid instrument for $\Delta h_{i t}$ to allow feedback effects from participation in firm-sponsored training to working hours. "2SLS, instrument $h_{i t-2}$ " refers to the model in which we use the 2SLS estimator with $h_{i t-2}$ as a valid instrument for $\Delta h_{i t}$ to further avoid reverse causality. 
part-time is positive and not significant $(+3.4$ percentage points).

When we estimate the model in first-difference by way of 2SLS, using the lag of order one of working hours $\left(h_{i t-1}\right)$ to instrument the first difference of working hours $\left(\Delta h_{i t}\right),{ }^{10}$ we make the estimation robust to the failure of the strict exogeneity assumption. In other words, we allow shocks in the dependent variable to affect future realizations of the working hours variable. From the qualitative point of view, the estimation results are in line with those from the first-difference OLS estimator: working hours have a significant and positive effect for men, but no effect for women. From a quantitative point of view, the effect for men is much larger: one more hour of work in a week implies a higher probability of receiving firm-sponsored training by about 2.8 percentage points; moving from full-time to part-time generates a reduction in the training probability by about 52 percentage points. These estimation results are confirmed by the 2SLS estimator using the lag of order two of working hours $\left(h_{i t-2}\right)$ to instrument the first difference of working hours $\left(\Delta h_{i t}\right)$. The $F$-test for excluded instrument is much lower and, for men, close to the weak instrument rule of thumb value of 10 identified by Staiger and Stock (1997). The estimation results from the 2SLS with $h_{i t-2}$ as excluded instrument should therefore be read with cautions, given that they might suffer from a bias due to weak instruments. It is worth noting that: the Hansen $J$ statistics reported at the bottom of each panel of Tables 5 and 6 seems to support the conditional orthogonality assumption of the instruments; ${ }^{11}$ the sample selection tests cannot reject the null hypothesis of no sample selection bias due to the non observability of training for individuals who do not participate to the labor market as employee. ${ }^{12}$

\footnotetext{
${ }^{10}$ The instrument has explanatory power both for men and women, as testified by the $F$-test for excluded instruments reported in Tables 5 and 6 (Staiger and Stock, 1997).

${ }^{11}$ As pointed out by Parente and Silva (2012), the overidentification test gives little information when the instruments measure the same process and, therefore, should be taken with caution.

${ }^{12}$ We use the number of the components of the household and the number of children living in the household as exclusion restrictions in the employment selection equation. This means that we assume that conditional on working hours, the other observables and, in the equations in first-differences, the individual fixed effect, the number of children and household components do not affect firm-sponsored training. This assumption is supported by the institutional set-up. In the last twenty years, the Dutch government has indeed implemented some policies aimed at removing barriers to part-time work, culminating in 2000 with the possibility for workers to flexibly adjust upward or downward the number of working hours within their current job, unless the request is in conflict with employers' business interest. Hence, family care, for instance due to the presence of kids, will be reflected and incorporated in the value of working hours. The results in Georgellis and Thomas (2007), who found that in Germany the number of children has a negative impact on employer-provided training for both men and women, seem to move against our assumption. However, Georgellis and Thomas (2007) do not control for working hours. In our model, when we include the number of kids among the set of regressors, its estimated coefficient is not significantly different from zero, for both men and women, and all the other results are left unchanged. These estimation results are not
} 


\section{TABLE 7: GENDER DIFFERENCES IN THE EFFECT OF WORKING HOURS ON FIRM-SPONSORED TRAINING (PREFERRED MODELS IN BOLD)}

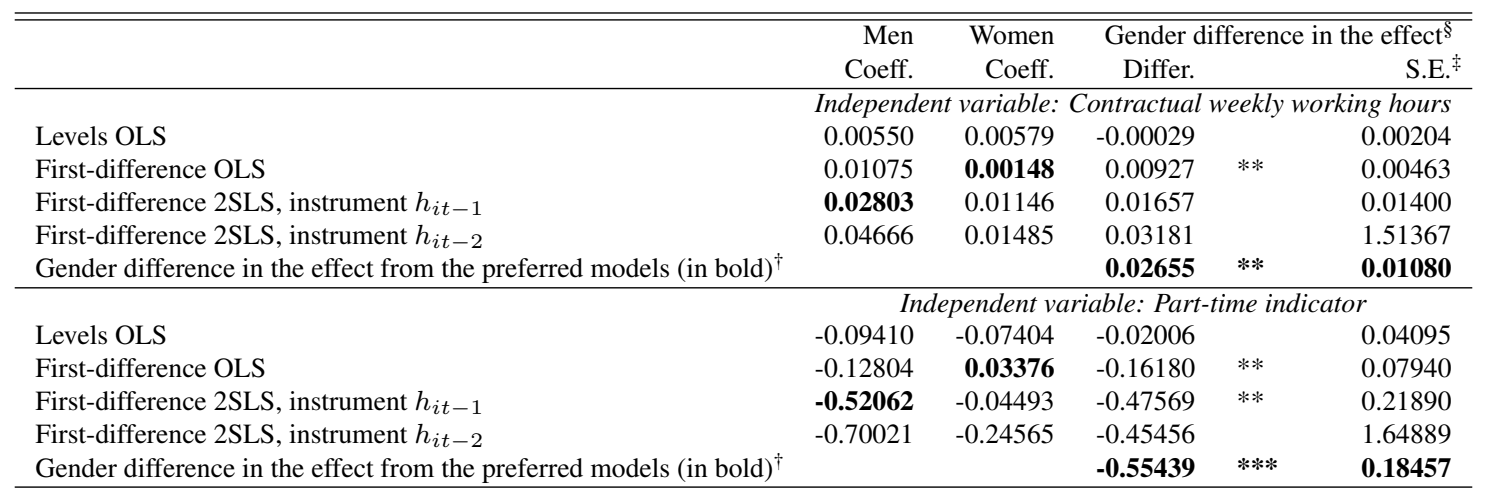

Notes: * Significant at $10 \%$ level; ** significant at $5 \%$ level; *** significant at $1 \%$ level. The standard errors are robust to heteroskedasticity and serial correlation.

$\S$ The gender difference of the effect is computed as the difference between the male effect and the female effect.

$\dagger$ The estimated coefficients of the preferred models are in bold. For men, the preferred estimator is first-difference 2SLS, with $h_{i t-1}$ as instrument, because the Hausman test reveals an endogeneity problem of the working hours variable in first-difference OLS and the Hansen $J$ statistic does not reveal any problem in the use of $h_{i t-1}$ as excluded instrument for $\Delta h_{i t}$. Since for women there is no evidence for the endogeneity of $\Delta h_{i t}$, the preferred estimator is first-difference OLS.

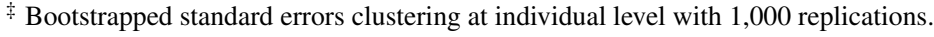

Table 7 summarizes the estimated coefficients of working hours displayed in Tables 5 and 6 and the gender difference in the effect. We report in bold our preferred estimates. For men, the preferred estimator is first-difference 2SLS with $h_{i t-1}$ as instrument, because: i) the Hausman test reveals an endogeneity problem of the working hours variable in first-difference OLS; ii) the Hansen $J$ statistic provides evidence that $h_{i t-1}$ and $h_{i t-2}$ identify the same vector of parameters. Since for women there is no evidence for the endogeneity of $\Delta h_{i t}$, the preferred estimator is first-difference OLS. Table 7 reports the gender difference in the effect of working hours on the propensity to receive firm-sponsored training both estimator by estimator and, in the last row of each panel, by comparing the male preferred estimate with the female one. We find that the gender difference in the effect is large and significantly different from zero. We conclude therefore that working hours affect firm-sponsored training for men but not for women: whilst working hours positively affect the training chances for men, it has no impact on female firm-sponsored training.

presented in the text but are available from the authors upon request. 


\section{The impact of other regressors on firm-sponsored training}

If we limit the comments on the impact of other regressors to the preferred models for men and women, it is clear that few other covariates have a significant impact on the probability of receiving firm-sponsored training. For men, job tenure plays an important role: it is an inverted U-shaped relationship with maximum at about 11 years and 4 months of job seniority. At this level of job seniority, the probability of firm-sponsored training is 10.2 percentage points higher than the one of newly hired workers (who are the reference). Then, it declines with job tenure until newly hired workers have the same probability of firm-sponsored training as workers with about 22 years and 8 months of job tenure. ${ }^{13}$

For women, job tenure is instead not correlated to firm-sponsored training. Being single has a negative effect, although significant only at the $10 \%$ level, maybe because it might be a proxy of a higher propensity to move from job to job. Finally, low skilled-white collar women are the most likely to be trained by their employers.

\subsection{Sensitivity analysis}

One could wonder that the estimated effect of working hours on the probability of receiving firm-sponsored training could be biased by the presence of unobservables at firm level. First-differencing indeed removes the time-constant unobservables at worker level, but it is not able to eliminate the time-constant unobservables at firm level if workers changed firms from the survey at time $t-1$ to the one at time $t$. The unobservables at firm level, like production technology, firm management and human resources practices, might be determinants of both the working hours and firm-sponsored training. Moreover, if the correlation between firm unobservables and the dependent and independent variables is related to gender, the presence of such firm heterogeneity might asymmetrically bias the estimated coefficients of men and women.

We check the robustness of our results to unobservables at firm level following two approaches. In the first one, we restrict the sample only to firm stayers, i.e. to those workers who do not change firm from one survey to the next one. ${ }^{14}$ For firm-stayers, first-differencing removes unobservables both at individual and firm level. This approach is in the spirit of Altonji and Shakotko (1978) and Topel (1991). However, by doing

\footnotetext{
${ }^{13}$ This contrasts with Bassanini et al. (2007), who found a U-shaped relationship between training and job tenure: training is more likely at low tenure and at high tenure. Job tenure is likely to be an endogenous variable and, therefore, we do not attempt to provide an interpretation to the estimated relationship.

${ }^{14} \mathrm{~A}$ firm identifier is not available in the LISS panel data. We use the information on the firm seniority declared by the individual and on the survey times to identify the "stayers".
} 
so, we possibly open the door to a sample selection problem (Topel, 1991), since stayers might not be a random sample from the underlying population of workers and the selection rule could depend on gender. Table 8 displays the estimation results from the first-difference OLS and 2SLS (with $\Delta h_{i t}$ instrumented by $h_{i t-1}$ ) estimators by gender. When the variable of primary interest is the part-time indicator, the estimated effects of the working time on firm-sponsored training are in line with those of the baseline model from the qualitative viewpoint: i) a large and significant reduction in the probability of firm-sponsored training for male working part-time with the same magnitude as in the benchmark estimates $(-0.474$ against -0.521$)$; ii) the effect is not significantly different from zero for women as in the benchmark estimates. ${ }^{15}$ When the variable of primary interest is contractual weekly working hours, the positive relation between working hours and firm-sponsored training shrinks to zero for men, with the gender gap becoming much narrower in magnitude. This might suggest that firm heterogeneity is important, or, as an alternative, that firm-stayers are not a random draw from the underlying population of workers (Topel, 1991) and the selection rule is gender specific.

TABLE 8: THE EFFECT OF WORKING HOURS ON THE PROBABILITY OF RECEIVING FIRM-SPONSORED TRAINING FOR FIRM STAYERS

\begin{tabular}{|c|c|c|c|c|c|c|c|}
\hline & \multicolumn{4}{|c|}{ Men } & \multicolumn{3}{|c|}{ Women } \\
\hline & Coeff & & Std. Err. & Observations & Coeff. & Std. Err. & Observations \\
\hline & \multicolumn{7}{|c|}{ Independent variable: Contractual weekly working hours } \\
\hline First difference OLS & 0.00302 & & 0.00363 & 3,924 & 0.00578 & 0.00342 & 4,294 \\
\hline First-difference 2SLS, instrument $h_{i t-1}$ & 0.02158 & & 0.01437 & 3,924 & 0.02024 & 0.01399 & 4,294 \\
\hline \multicolumn{8}{|l|}{ Tests after $2 S L S$} \\
\hline F-test of excluded instruments & \multirow{2}{*}{\multicolumn{4}{|c|}{$\begin{array}{c}30.73 \\
\mathrm{~F}(1,1367)=2.00, p \text {-value }=0.158\end{array}$}} & \multicolumn{3}{|c|}{98.01} \\
\hline \multirow[t]{2}{*}{ Hausman test of endogeneity } & & & & & $\mathrm{F}(1$, & $=1.14, p-\mathrm{v}$ & $\mathrm{e}=0.285$ \\
\hline & \multicolumn{7}{|c|}{ Independent variable: Part-time indicator } \\
\hline First difference OLS & 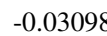 & & 0.07494 & 3,924 & -0.01989 & 0.04693 & 4,294 \\
\hline First-difference 2SLS, instrument $h_{i t-1}$ & -0.47352 & $* *$ & 0.22373 & 3,924 & -0.13153 & 0.18438 & 4,294 \\
\hline \multicolumn{8}{|l|}{ Tests after $2 S L S$} \\
\hline F-test of excluded instruments & \multirow{2}{*}{\multicolumn{4}{|c|}{$\begin{array}{c}19.21 \\
\mathrm{~F}(1,1367)=5.10, p \text {-value }=0.024\end{array}$}} & \multicolumn{3}{|c|}{122.94} \\
\hline Hausman test of endogeneity & & & & & $\mathrm{F}(1$, & $=0.40, p-v_{i}$ & $\mathrm{e}=0.526$ \\
\hline
\end{tabular}

Notes: * Significant at $10 \%$ level; ** significant at $5 \%$ level; *** significant at $1 \%$ level. The standard errors are robust to heteroskedasticity and serial correlation. Firm movers are deleted from the sample, explaining the reduced sample size with respect to the sample of the baseline models. We drop from the list of explanatory variables job and firm characteristics, since either they do not vary over time for firm stayers or their time variation is too little. We report in bold the estimation results of the preferred models according to the diagnostic test after 2SLS estimation.

In order to shed more light on the importance of firm unobservables we implement

\footnotetext{
${ }^{15}$ Differently from the benchmark estimates, for female firm-stayers working part-time decreases the chances of firm-sponsored training. However, the effect is not precisely estimated.
} 
a second check consisting in using a control function approach and, therefore, in plugging into the main equation a further set of covariates to capture eventual heterogeneity related to firm and job characteristics. First, we included a set of twelve dummy variables describing the job performed by the employee along several dimensions multiplied by job seniority in days: if the employee can work at his/her own pace, if the work implies getting dirty, if the work is dangerous, if the employee is in contact with hazardous substances, if the work is physically demanding, if the work implies lifting heavy objects, if it requires kneeling or stooping, if it is tiring, if it implies mental effort, if concentration is needed, if the work requires getting too busy and if it demands to relate well to other people. Second, we interact among each other all the indicators of firm heterogeneity at the finest level observed in the original dataset: sector, firm size and the indicator for the firm being public or private. We identify therefore 161 non-empty cells. We multiply the corresponding dummy variables by job seniority in days and we plug the resulting variables into the main equation among the other covariates. The idea of using these higher-order interactions between observables characteristics at individual, job and firm levels is in the same spirit of the approximation of the correlation between the firm fixed effects and individual characteristics in Abowd et al. (1999). Table 9 displays the estimation results when we augment the set of regressors by these higher order interactions of firm characteristics and job type indicators. The estimated coefficients are very close to those reported in Table 7.

TABLE 9: THE EFFECT OF WORKING HOURS ON THE PROBABILITY OF RECEIVING FIRM-SPONSORED TRAINING AFTER INCLUDING INTERACTIONS OF FIRM CHARACTERISTICS AND FURTHER JOB CHARACTERISTICS

\begin{tabular}{|c|c|c|c|c|c|c|c|c|}
\hline & \multicolumn{4}{|c|}{ "Men } & \multicolumn{3}{|c|}{ Women } & \multirow[b]{2}{*}{ Observations } \\
\hline & Coeff. & & S.E. & Observations & Coeff. & & S.E. & \\
\hline & \multicolumn{8}{|c|}{ Independent variable: Contractual weekly working hours } \\
\hline Levels OLS & 0.00530 & $* * *$ & 0.00181 & 6,128 & 0.00529 & $* * *$ & 0.00102 & 6,776 \\
\hline First-difference OLS & 0.01078 & $* * *$ & 0.00345 & 4,565 & 0.00191 & & 0.00285 & 5,034 \\
\hline First-difference 2SLS, instrument $h_{i t-1}$ & 0.02859 & $* * *$ & 0.01031 & 4,565 & 0.01054 & & 0.00925 & 5,034 \\
\hline \multirow[t]{2}{*}{ First-difference 2SLS, instrument $h_{i t-2}$} & 0.04642 & & 0.02943 & 3,002 & 0.01144 & & 0.01641 & 3,292 \\
\hline & \multicolumn{8}{|c|}{ Independent variable: Part-time indicator } \\
\hline Levels OLS & -0.10002 & $* * *$ & 0.03729 & 6,128 & -0.06588 & $* * *$ & 0.01645 & 6,776 \\
\hline First-difference OLS & -0.12187 & $*$ & 0.06357 & 4,565 & 0.03063 & & 0.04059 & 5,034 \\
\hline First-difference 2SLS, instrument $h_{i t-1}$ & -0.49653 & $* * *$ & 0.17802 & 4,565 & -0.04122 & & 0.12985 & 5,034 \\
\hline First-difference 2SLS, instrument $h_{i t-2}$ & -0.63879 & & 0.57434 & 3,002 & -0.17692 & & 0.24657 & 3,292 \\
\hline
\end{tabular}


A third sensitivity analysis involves the specification of the main equation and the possible presence of biases in its estimation due to possible correlation between unobservables and changes in working hours. As a matter of fact, those individuals who decide to modify their contractual working hours could be a selected sample of the population: individuals that are more ambitious, attached to the labor market and career oriented could be less likely to experience a reduction in working time and more likely to get firm-sponsored training. The variation in working hours could therefore be time-varying heterogeneity if not included among the regressors. We therefore modify Equation (1) by including $\Delta h_{i t}$ among the regressors:

$$
P\left(y_{i t}=1 \mid h_{i t}, \mathbf{x}_{i t}, c_{i}\right)=\delta h_{i t}+\alpha \Delta h_{i t}+\mathbf{x}_{i t}^{\prime} \boldsymbol{\beta}+c_{i}
$$

We estimate this equation using the same strategy as in the benchmark model: OLS in levels ignoring $c_{i}$; OLS after first differencing so as to remove $c_{i}$; 2SLS after first differencing using $h_{i t-1}$ as an instrument for $\Delta h_{i t}$ and $\Delta h_{i t-1}$ as an instrument for $\Delta \Delta h_{i t-1}$. The inclusion of $\Delta h_{i t}$ among the regressors makes us lose one time period and the source of identification, the within-individual time variation, shrinks further. We therefore run this sensitivity check only using the contractual weekly working hours as measure of working time. Table 10 displays the estimation results of the coefficients of $h_{i t}$ and $\Delta h_{i t}$. They are very much in line with those of the benchmark model and the estimated coefficients of $\Delta h_{i t}$ are never significantly different from zero.

TABLE 10: ESTIMATION OF THE FIRM-SPONSORED TRAINING EQUATION INCLUDING THE VARIATION IN THE CONTRACTUAL WORKING HOURS $\left(\Delta h_{i t}\right)$ AMONG THE REGRESSORS

\begin{tabular}{|c|c|c|c|c|c|c|c|c|c|}
\hline & & \multicolumn{4}{|c|}{ Men } & \multicolumn{4}{|c|}{ Women } \\
\hline & & Coeff. & & Std. Err. & Obs. & Coeff. & & Std. Err. & Obs. \\
\hline \multirow{2}{*}{ Levels OLS } & $h_{i t}$ & 0.00477 & $* *$ & 0.00220 & \multirow{2}{*}{4,565} & 0.00519 & $* * *$ & 0.00113 & \multirow{2}{*}{5,034} \\
\hline & $\Delta h_{i t}$ & 0.00013 & & 0.00338 & & -0.00256 & & 0.00222 & \\
\hline \multirow{2}{*}{ First difference OLS } & $h_{i t}$ & 0.01242 & $*$ & 0.00651 & \multirow{2}{*}{3,002} & 0.00390 & & 0.00410 & \multirow{2}{*}{3,292} \\
\hline & $\Delta h_{i t}$ & -0.00535 & & 0.00454 & & -0.00443 & & 0.00306 & \\
\hline \multirow{2}{*}{$\begin{array}{l}\text { First-difference } 2 \text { SLS, } \\
\text { instruments } h_{i t-1} \text { and } \Delta h_{i t-1} \\
\text { Tests after } 2 S L S\end{array}$} & $h_{i t}$ & 0.03781 & $*$ & 0.02143 & \multirow{2}{*}{3,002} & 0.01269 & & 0.01425 & \multirow{2}{*}{3,292} \\
\hline & $\Delta h_{i t}$ & -0.00927 & & 0.00547 & & -0.00524 & & 0.00338 & \\
\hline \multirow{3}{*}{$\begin{array}{l}\text { F-test of excluded instruments } \\
\text { Hausman test of endogeneity }\end{array}$} & $\Delta h_{i t}$ & \multicolumn{4}{|c|}{$\begin{array}{c}18.50 \\
373.42\end{array}$} & \multirow{2}{*}{\multicolumn{4}{|c|}{$\begin{array}{c}45.93 \\
873.80\end{array}$}} \\
\hline & $\Delta \Delta h_{i t}$ & & & 3.42 & & & & & \\
\hline & & \multicolumn{4}{|c|}{$\mathrm{F}(2,1080)=3.18, p$-value $=0.042$} & \multicolumn{4}{|c|}{$\mathrm{F}(2,1158)=1.92, p$-value $=0.147$} \\
\hline
\end{tabular}

Notes: * Significant at $10 \%$ level; ** significant at $5 \%$ level; *** significant at $1 \%$ level. The standard errors are robust to heteroskedasticity and serial correlation. The reduction in the number of observations is due to the fact that, when we include $\Delta h_{i t}$ among the regressors, we lose one time period. 
We run a fourth sensitivity check to test whether measurement error might be an issue in the first difference estimation. As a matter of fact, errors of measurement in the explanatory variables get magnified by the reduced variation implied by the elimination of the unobserved heterogeneity (Griliches and Hausman, 1986). One may wonder that gender differences in the effect of working hours on firm-sponsored training is not due to economic reasons, but to a gender difference in the attenuation bias generated by gender specific measurement errors. For example, on the one hand, if women change working time more often, then they might be more likely than men to mis-report the actual working time; on the other hand, if very few men modify their working time and maybe they do it under very special circumstances, then they could be more likely to exactly report the new working time regime. We assume that the measurement error is uncorrelated to the explanatory variables and we correct for the potential bias induced by the measurement error by using the variation in desired working hours to instrument the variation in working hours $\Delta h_{i t}$. Then, using a regression based Hausman test (robust to heteroskedasticity and within-individual correlation), we tested whether the measurement error corrected estimation of the parameter of contractual working hours is different from the one that ignores the measurement error. Table 11 displays the Hausman test statistics. Since not all the individuals reported the number of desired working hours, the number of observations is smaller than the one in the benchmark approach. The variation of the desired working hours have a weak explanatory power in explaining $\Delta h_{i t}$ for men. However, it is strong enough for women who, as said, might be more likely to report incorrectly their contractual working hours. According to what we can infer from Table 11, it seems that measurement error is not an issue.

Since in the LISS panel we also have information about individuals' training activities which are not sponsored by firms, we re-estimated all the baseline models by including an indicator variable equal to one if the worker participated in a training course not sponsored by the firm in the last 12 months (and zero otherwise). Participation in other training course is a time-varying variable which could be correlated to both the probability of firmsponsored training and working hours. Omitting this source of time-varying heterogeneity might bias the estimation results. When we include the indicator for training not sponsored by the firm in the set of control variables, we get estimation results, significance levels and diagnostic tests after 2SLS estimates that are indistinguishable from those of the baseline models. ${ }^{16}$ Since the process of attending training courses not sponsored by

\footnotetext{
${ }^{16}$ The estimation results of the equations augmented by the indicator for training not sponsored by the firm are available from the authors upon request. We find that firm-sponsored training and training not sponsored by the firm are negatively correlated for both men and women.
} 
TABLE 11: TESTS FOR MEASUREMENT ERROR USING THE DESIRED WORKING HOURS AS INSTRUMENT FOR CONTRACTUAL WORKING TIME

\begin{tabular}{|c|c|c|c|c|c|c|c|c|}
\hline & \multicolumn{4}{|c|}{ Men } & \multicolumn{4}{|c|}{ Women } \\
\hline & $\begin{array}{r}\text { Hausman } \\
\text { statistic }^{\dagger}\end{array}$ & $p$-value & $\begin{array}{c}F \text {-test excluded } \\
\text { instruments }\end{array}$ & Observ. $^{\S}$ & $\begin{array}{r}\text { Hausman } \\
\text { statistic }^{\dagger}\end{array}$ & $p$-value & $\begin{array}{c}F \text {-test excluded } \\
\text { instruments }\end{array}$ & Observ. ${ }^{\S}$ \\
\hline \multicolumn{9}{|c|}{ Independent variable: contractual weekly working hours } \\
\hline First difference OLS & 1.778 & 0.183 & 1.46 & 4,063 & 0.003 & 0.955 & 45.60 & 4,490 \\
\hline $\begin{array}{l}\text { First-difference 2SLS, } \\
\text { instrument } h_{i t-1}\end{array}$ & 1.334 & 0.248 & 16.08 & 4,063 & 0.505 & 0.477 & 68.64 & 4,490 \\
\hline & \multicolumn{8}{|c|}{ Independent variable: part-time indicator } \\
\hline First difference OLS & 1.778 & 0.183 & 5.76 & 4,063 & 0.047 & 0.829 & 38.05 & 4,490 \\
\hline $\begin{array}{l}\text { First-difference 2SLS, } \\
\text { instrument } h_{i t-1}\end{array}$ & 2.720 & 0.099 & 11.82 & 4,063 & 0.896 & 0.344 & 84.97 & 4,490 \\
\hline
\end{tabular}

$\dagger$ The Hausman test statistics are robust to heteroskedasticity and within-individual correlation.

$\S$ The number of observations is smaller than the one in the benchmark models because not all the individuals reported the number of desired working hours.

the firm might be realized simultaneously to the process of receiving firm-sponsored training, we prefer to stick to the models without the indicator for training not sponsored by the firm as a benchmark.

\subsection{How to explain our findings}

In the previous subsection, we showed that low working hours lower the chances of a male worker to receive firm-sponsored training. For women, there is instead no effect of working hours on firm-sponsored training. In this subsection, we try to answer the question of why there is an effect for men but not for women.

As pointed out by Backes-Gellner et al. (2014), one of the most important determinant of the firm propensity to provide their workers with training is the expected future working time volume of the match between the firm and a given worker. The larger the future working time volume of the match, the higher indeed the probability that the employer will recoup the training costs. As a matter of fact, Picchio and van Ours (2011) found that the higher the degree of monopsony power, and therefore the lower the potential mobility of workers, the higher the training investments of firms in the Netherlands. Ikenaga and Kawaguchi (2013) studied the relationship between labor market attachment and training participation in Japan, finding that workers' expected attachment to the labor market and expected tenure at a specific firm mainly explain participation in employer-provided training. Because of labor market imperfections employers may have some monopsony power 
over workers. This allows them to reap some of the benefits of training by increasing the gap between productivity and wage (Acemoglu, 1997; Acemoglu and Pischke, 1999). It could be that our findings on the gender-specific relationship between part-time work and firm-sponsored training are related to gender-specific monopsony power of firms. Indeed, there is some evidence that employers have more monopsony power over female workers than they have over male workers (Hirsch et al., 2010; Ransom and Oaxaca, 2010). If so, this would make it more worthwhile for employers to invest in training of their female workers. However, for a monopsony power explanation of our findings there should be gender-working hours based differences in monopsony power.

Hence, one possible explanation for the gender difference in the effect is that the contractual weekly working hours could be a better proxy of the stability of the job match for men than for women. Being a man working little hours could mean that the male worker is performing a bad job, a temporary situation, while for women working a reduced number of hours could be a permanent choice, a way to reconcile career and family care. We test whether this might be an explanation of our findings by studying how the contractual weekly working hours at time $t$ affect the probability of leaving the current firm in the subsequent 12 months. If working hours are a better predictor of expected job attachment and job tenure for men than for women, this should be reflected in a larger positive effect of working part-time on the probability of leaving the current firm for men than for women. The top panel of Table 12 reports the estimation results of a linear probability model for leaving the current firm in one year as a function of contractual weekly working hours and all the covariates used in the baseline model. We use different estimator and report in bold the estimation results of the preferred models for men and women, chosen on the basis of the 2SLS diagnostic tests. We conclude that a lower number of working hours or having a part-time job is an indicator of short duration neither for men nor for women.

As a further check in this direction, we studied the relation between working hours and the probability of training not sponsored by the firm. If a part-time position is less stable for men than for women, then male part-timers should more willing than female part-timers to be involved in training activities not sponsored by the firm, so as to acquire more general skills and be more likely to get a more stable position in some other firm. The bottom panel of Table 12 reports the estimation results of a linear probability model for training not sponsored by the firm as a function of contractual weekly working hours and all the covariates used in the baseline model. We find no effect of contractual weekly working hours on training not sponsored by the firm and no gender difference. 
TABLE 12: THE EFFECT OF CONTRACTUAL WEEKLY WORKING HOURS ${ }^{\S}$ ON THE PROBABILITY OF: A) LEAVING THE CURRENT FIRM IN ONE YEAR; B) TRAINING NOT SPONSORED BY THE FIRM

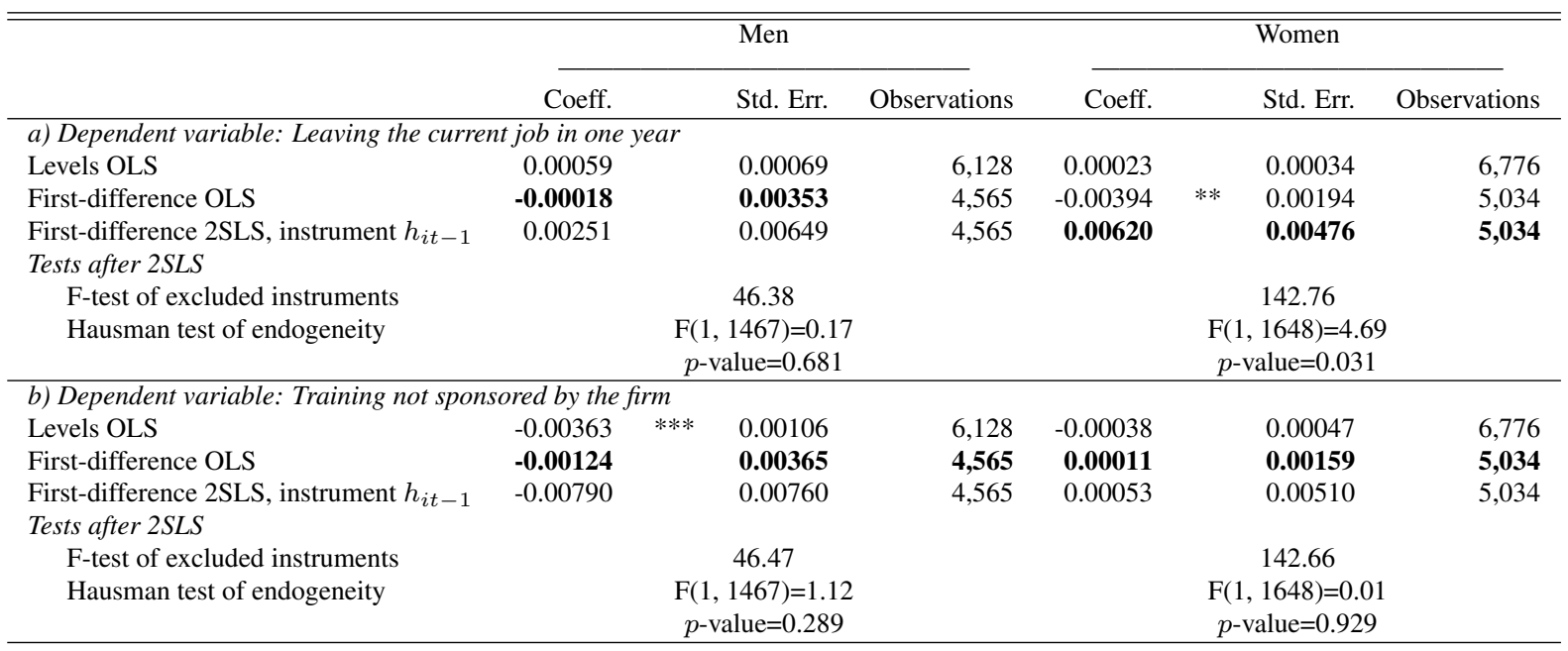

Notes: * Significant at $10 \%$ level; ** significant at $5 \%$ level; *** significant at $1 \%$ level. The standard errors are robust to heteroskedasticity and serial correlation. We report in bold the estimation results of the referred models according to the diagnostic test after 2SLS estimation. All the covariates of the baseline model plus the indicator for firm-sponsored training are included as regressors.

$\S$ We also estimated similar models but using the part-time indicator as a measure of working hours. We obtained very similar results from the qualitative viewpoint. They are not reported for the sake of brevity, but they are available from the authors upon request. 
If the gender difference in the effect of working hours on firm-sponsored training is induced by a different level of job stability between male and female part-timers, this might be reflected on different levels of job satisfaction between men and women (conditional on working hours). If the degree of job stability is decreasing in working hours for men, then we should observe a positive relationship between male job satisfaction and working hours. The LISS panel contains several variables measuring the employees' satisfaction from different angles: work, career, wage, working hours, work type and atmosphere with colleagues satisfaction. The question about job satisfaction is specified as follows: "How satisfied are you with [...]?" with the possible answers ranging in the set of positive integers from 0 (very dissatisfied) to 10 (very satisfied). We estimate therefore fixed effects ordered logit models for these different measures of job related satisfaction to understand whether and how they are affected by working hours. We use the fixed-effects ordered logit estimator suggested by Mukherjee et al. (2008), named 'blow-up and cluster' (BUC) by Baetschmann et al. (2015), who studied its properties and compared them to those of alternative estimators. Table 13 reports the estimation results of the satisfaction equations by gender and it shows that for men all the measures of job satisfaction are not affected by working hours. For women, we find instead some evidence of a significant and positive effect of working hours on wage satisfaction but a negative and significant effect on working hours satisfaction.

therefore, the explanation of why we find an effect of working hours on firm-sponsored training for men but not for women does not seem to be linked to the actual job stability of male and female part-timers. However, the time period over which we can compare for example job stability is rather short. Therefore, we cannot rule out that there are gender-working hours specific differences in monopsony power. Nevertheless, we speculate that our findings might also be related to social norms. We saw in Section 2 that in the Netherlands for women it is quite common to work part-time. More than half of the female prime age employees work part-time. Men working part-time are much less common in the Netherlands. The large gender difference in the share of men and women with a part-time job might have shaped social norms according to which men working parttime could send a very different signal to their employer than women working part-time. The employer might interpret this preference as a signal of low attachment to the labor market or low interest in that particular job, and thereby of short expected duration of the job relationship. This might generate a different propensity of firms to sponsor training of male part-timers than female part-timers. Since it is instead common for women to choose part-time positions, the preference of a female worker for a reduced number of 


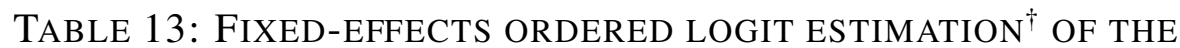 EFFECT OF WORKING HOURS ON DIFFERENT MEASURES OF WORK-RELATED SATISFACTION}

\begin{tabular}{|c|c|c|c|c|c|}
\hline \multirow[b]{2}{*}{ Dependent variables ${ }^{\S}$} & \multicolumn{2}{|c|}{ Men } & \multicolumn{3}{|c|}{ Women } \\
\hline & Coeff. & Std. Err. & Coeff. & & Std. Err. \\
\hline & \multicolumn{5}{|c|}{ Effect of contractual weekly working hours on satisfaction } \\
\hline Work satisfaction & -0.01000 & 0.01900 & 0.01060 & & 0.01236 \\
\hline Career satisfaction & -0.00778 & 0.01837 & 0.01844 & & 0.01326 \\
\hline Wage satisfaction & -0.01230 & 0.01960 & 0.02764 & ** & 0.01239 \\
\hline Working hours satisfaction & 0.00046 & 0.02035 & -0.03883 & $* * *$ & 0.01420 \\
\hline Work type satisfaction & -0.01080 & 0.01933 & 0.00566 & & 0.01419 \\
\hline \multirow[t]{2}{*}{ Atmosphere with colleagues satisfaction } & -0.02963 & 0.02272 & 0.01118 & & 0.01303 \\
\hline & \multicolumn{5}{|c|}{ Effect of working part-time on satisfaction } \\
\hline Work satisfaction & 0.25328 & 0.33100 & -0.04021 & & 0.17890 \\
\hline Career satisfaction & 0.14641 & 0.37127 & -0.06255 & & 0.18632 \\
\hline Wage satisfaction & 0.35435 & 0.34772 & -0.09843 & & 0.19153 \\
\hline Working hours satisfaction & 0.15710 & 0.36357 & 0.43600 & ** & 0.20407 \\
\hline Work type satisfaction & 0.41507 & 0.34905 & 0.08162 & & 0.19361 \\
\hline Atmosphere with colleagues satisfaction & 0.39625 & 0.47575 & -0.23802 & & 0.17249 \\
\hline
\end{tabular}

Notes: * Significant at $10 \%$ level; ** significant at $5 \%$ level; *** significant at $1 \%$ level. The standard errors are robust to heteroskedasticity and serial correlation. All the covariates used in the baseline model plus the indicator for firm-sponsored training are included as regressors in the equation for the different measures of work-related satisfaction.

$†$ We implement the 'blow-up and cluster' (BUC) fixed-effects ordered logit estimator suggested by Mukherjee et al. (2008). We control also for all the covariates used in the baseline models in firstdifferences.

$\S$ The dependent variables take values on the set of integer values in $[0,10]$, where 0 means "not at all satisfied" and 10 means "fully satisfied".

working hours might not convey a bad signal to the employer. Gender asymmetries in the type of signal sent by the preference for a reduced number of working hours might therefore explain why we find a different propensity of firms to sponsor training of male part-timers than that of female part-timers. Since we found no evidence of correlations between working hours and future job stability and satisfaction, it might imply that social norms are generating signals that do not reflect the actual attachment to the labor market of male part-timers. If so, employers are allocating resources on training programs on the basis of mis-perceived expected future working time volume of the match between the firm and a given worker.

Finally, we investigate whether there are gender-specific differences in the part-time pay penalty, i.e. in the hourly wages of part-timers and full-timers. The top panel of Table 14 shows the relevant parameter estimates when we relate contractual weekly working hours to hourly wages. When using OLS we find for both men and women that the hourly wage decreases with the number of working hours. In the bottom part of Table 14 we also find that part-timers have a higher hourly wage than full-timers. However, both 
relationships may be caused by unobserved personal characteristics such that conditional on observables more skillful individuals are more likely to have fewer working hours, i.e. work part-time. Therefore, we also present estimates where we allow for individuals fixed effects. The parameter estimates are presented in the second rows of both the upper and lower panel of Table 14. Now we find that for men the point estimates are very much in line with those from the OLS estimator in levels: a Hausman test comparing the levels OLS estimates with the first difference OLS estimates does not reject the null hypothesis that working time is exogenous in the model in levels, when we use both the contractual weekly working hours and the part-time indicator. For women, removing the individual fixed effects by first differencing results instead in a significantly different estimate of the parameter of the contractual weekly working hours. ${ }^{17}$ After looking also at the Hausman test statistics comparing the first difference OLS estimates to the first difference 2SLS estimate (with $h_{i t-1}$ as instrument for $\Delta h_{i t}$ ), the preferred estimates are: i) the levels OLS for men; ii) for women, the first difference 2SLS estimate when using the contractual weekly working hours and the levels OLS estimate with the part-time indicator. According to the preferred estimates, which are reported in bold in Table 14, and if we take the hourly wage as an indicator of productivity, we conclude that parttimers are more productive than full-timers, for both men and women.

We can only speculate on the reason for this. Perhaps the higher productivity of parttimers is related to the combination of work and care. Studying the relationship between hours of housework and hours of market work for partnered individuals of whom the man works full-time Booth and van Ours (2013) conclude that for women increasing hours of market work is not compensated by an equivalent reduction of hours of housework. ${ }^{18}$ As the hours of market work of the women increase, man's hours of housework remain almost constant while for women there is approximately half an hour reduction of housework for every additional hour of market work. So, the net increase of working hours for every additional market hour is half an hour. Full-time working women may be less productive than part-time working women because they have a lot of hours of housework to do. We

\footnotetext{
${ }^{17}$ We computed the Hausman test statistics robust to heteroskedasticity and within-individual correlation by bootstrapping 999 times the difference between the OLS and the first difference estimates of the parameter of the working time variable. For men the Hausman test statistic is $\chi^{2}(1)=0.147$ ( $p$-value $=0.701$ ) and $\chi^{2}(1)=0.187$ ( $p$-value $\left.=0.666\right)$, respectively for the contractual weekly working hours variable and the part-time dummy; for women we get $\chi^{2}(1)=4.265(p$-value $=0.039)$ and $\chi^{2}(1)=0.077(p$-value $=0.781$ ), respectively for the contractual weekly working hours variable and the part-time dummy.

${ }^{18}$ Housework includes preparation of lunch/dinner, making table ready for dinner, doing the dishes, vacuum cleaning, cleaning windows/doors, doing the floors, cleaning toilet/bathroom, waxing floor and cleaning furniture, cleaning the beds, washing clothes, drying clothes, ironing clothes, fixing clothes and watering plants inside the house.
} 
also note that, not only part-timers might be more productive than full-timers on an hourly basis, but they could be more productive for firms on a weekly basis since they allow for more organizational flexibility than full-timers (see Künn-Nelen et al., 2013).

TABLE 14: THE EFFECT OF WORKING HOURS ON THE LOG HOURLY WAGES

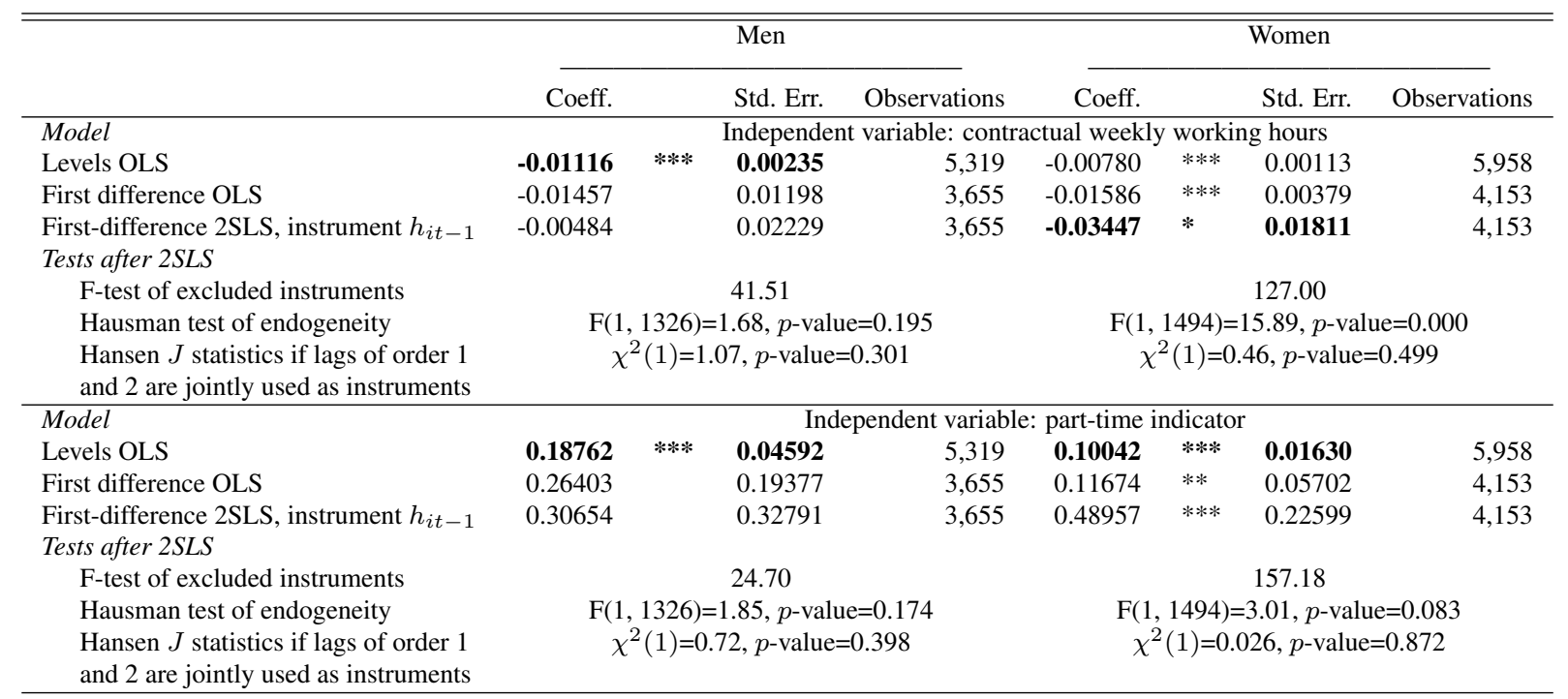

Notes: * Significant at $10 \%$ level; $* *$ significant at $5 \%$ level; *** significant at $1 \%$ level. The standard errors are robust to heteroskedasticity and serial correlation. We report in bold the estimation results of the preferred models according to the diagnostic tests after 2SLS estimation. We include in the log hourly wage equation all the covariates used in the baseline model plus an indicator for firm-sponsored training. We lose observations compared to the benchmark estimates because not all the workers report the monthly income, which is used to compute the average hourly wage, and because we exclude those individuals who worked zero hours in the month of the survey interview.

\section{Conclusions}

Using longitudinal data on workers in the Netherlands and focusing on the differences between males and females, we study the effect of working hours on the propensity of firms to sponsor training of their employees. On average, both part-time working men and part-time working women are less likely to receive firm-sponsored training than their full-time working counterparts. This is still the case if we allow for observed personal characteristics to influence the probability to receive firm-sponsored training. However, once we account for differences in unobserved personal characteristics we no longer find that part-time working women receive less firm-sponsored training than full-time working women. Apparently, for women the part-time specific difference in the likelihood of 
receiving training is related to unobserved characteristics and not to the working hours. For men, allowing for differences in unobserved characteristics does not remove the parttime training penalty. Allowing for potential endogeneity of working part-time we still find a difference in training propensity between part-time and full-time working men but no such difference for women. In this respect our findings are similar to what BackesGellner et al. (2014) find for Switzerland. However, different from the Swiss study we do not find a gender-specific difference in training incidence for full-time workers.

We investigate several possible explanations for the gender-specific differences in the part-time training penalty. We study whether they are related to gender-specific type of work by investigating whether unobserved firm differences matter but find that this is not the case. We also investigate whether job stability is an issue. If part-time working men are less likely to stay at a firm while part-time working women stay longer it does not pay for firms to make a training investment in part-time working men. We find no evidence for this. We also find no differences in job satisfaction between part-timers and full-timers. All this suggests that differences in monopsony power over part-time working men or part-time working men are not relevant. However, the time period over which we can compare, for example, job stability is rather short. Therefore, we cannot rule out that there are gender-working hours specific differences in monopsony power. Nevertheless, we speculate that the reason for part-time working women to be as likely to receive firmsponsored training as full-time working women is related to social norms. Whereas in the Netherlands working part-time is well-established for women, this is less common for men. Employers interpret a man working part-time as signaling a lower attachment to the job. We find no evidence that, at least in the short run, this is the case. It could be that employers are allocating resources on training programs on the basis of mis-perceived expected future working time volume of the match between the firm and a given worker. This opens the door to the intervention of the policy maker, which could aim at realigning the signal sent by male part-timers to their actual attachment to the labor market.

\section{References}

Abowd, J.M., F. Kramarz, and D.N. Margolis (1999) 'High wage workers and high wage firms.' Econometrica $67(2), 251-333$

Acemoglu, D. (1997) 'Training and innovation in an imperfect labour market.' Review of Economic Studies 64(3), 445-464

Acemoglu, D., and J.S. Pischke (1999) 'Beyond Becker: Training in imperfect labour markets.' Economic Journal 109(453), F112-F142 
Altonji, J.G., and R.A. Shakotko (1978) 'Do wages rise with seniority.' Review of Economic Studies 54(3), 437-459

Backes-Gellner, U., Y. Oswald, and S. Tuor Sartore (2014) 'Part-time employment - boon to women but bane to men? New insights on employer-provided training.' KYKLOS 67(4), 463-481

Baetschmann, G., K.E. Staub, and R. Winkelmann (2015) 'Consistent estimation of the fixed effects ordered logit model.' Journal of the Royal Statistical Society Series A 178(3), 685-703

Bassanini, A., A.L. Booth, G. Brunello, M. De Paola, and E. Leuven (2007) 'Workplace training in Europe.' In Education and Training in Europe, ed. Giorgio Brunello, Pietro Garibaldi, and Etienne Wasmer (Oxford: Oxford University Press) pp. 143-343

Blázquez Cuesta, M., and J. Moral Carcedo (2014) 'Women’s part-time jobs: "flexirisky" employment in five European countries.' International Labour Review, Vol. 153 (2014), No. 2 153(2), 269-292

Blundell, Richard, Lorraine Dearden, and Costas Meghir (1996) The Determinants and Effects of WorkRelated Training in Britain (London: Institute for Fiscal Studies)

Boeri, Tito, and Jan Cornellis van Ours (2013) The Economics of Imperfect Labor Markets (Princeton: Princeton University Press)

Booth, Alison, and Jan C. van Ours (2013) 'Part-time jobs: What women want?' Journal of Population Economics 26, 263-283

Bosch, N., A. Deelen, and R. Euwals (2010) 'Is part-time employment here to stay? Working hours of Dutch women over successive generations.' Labour 24, 35-54

Bosch, N., and B. van der Klaauw (2012) 'Analyzing female labor supply evidence from a Dutch tax reform.' Labour Economics 19, 271-280

Chamberlain, G. (1992) 'Comment: Sequential moment restrictions in panel data.' Journal of Business and Economic Statistics 10(1), 20-26

Connolly, Sara, and Mary Gregory (2009) 'The part-time pay penalty: Earnings trajectories of British women.' Oxford Economic Papers 61, i76-i97

Dostie, B. (2015) 'Who benefits from firm-sponsored training?' IZA World of Labor 145, 1-10

Euwals, R., and M. Hogerbrugge (2006) 'Explaining the growth of part-time employment.' Labour 20, 533557

Georgellis, Y., and L. Thomas (2007) 'Intervention at the level of the firm: Employer-sponsored training and wage growth in post-unification Germany.' International Journal of Manpower 28(1), 62-74

Griliches, Z., and J.A. Hausman (1986) 'Errors in variables in panel data.' Journal of Econometrics 31(1), 93-118

Hirsch, B. T., T. Schank, and C. Schnabel (2010) 'Differences in labor supply to monopsonistic firms and the gender pay gap: An empirical analysis using linked employer-employee data from Germany.' Journal of Labor Economics 28(2), 291-330 
Ikenaga, T., and D. Kawaguchi (2013) 'Labour market attachment and training participation.' Japanese Economic Review 64(1), 73-97

Knoef, M., and K. de Vos (2009) 'Representativeness in online panels: How far can we reach?' mimeo, Tilburg University, http://www.lissdata.nl/dataarchive/hosted_files/download/442

Künn-Nelen, A., A. de Grip, and D. Fouarge (2013) 'Is part-time employment beneficial for firm productivity?' Industrial and Labor Relations Review 66(5), 1172-1191

Mukherjee, B., J. Ahn, I. Liu, P.J. Rathouz, and B.N. Sanchez (2008) 'Fitting stratified proportional odds models by amalgamating conditional likelihoods.' Statistics in Medicine 27(24), 4950-4971

Parente, P.M.D.C, and J.M.C. Silva (2012) 'A cautionary note on tests of overidentifying restrictions.' Economics Letters 115(2), 314-317

Picchio, M., and J.C. van Ours (2011) 'Market imperfections and firm-sponsored training.' Labour Economics 18(5), 712-722

_ (2013) 'Retaining through training even for older workers.' Economics of Education Review 32(1), 29-48

Portegijs, W., M. Cloin, S. Keuzenkamp, A. Merens, and E. Steenvoorden (2006) Verdeelde tijd; waarom vrouwen in deeltijd werken ("Divided time; why women work part-time") (Sociaal and Cultureel Planbureau, Den Haag)

Ransom, M. R., and R. L. Oaxaca (2010) 'New market power models and sex differences in pay.' Journal of Labor Economics 28(2), 267-289

Salladarré, F., and S. Hlaimi (2014) 'Women and part-time work in Europe.' International Labour Review 153(2), 293-310

Scherpenzeel, A. (2010) 'How to cover the general population by internet interviewing: Problems of coverage and selection and possible solutions.' Alert! Magazine

_ (2011) 'Data collection in a probability based internet panel: How the LISS panel was built and how it can be used.' Bulletin of Sociological Methodology 109(1), 56-61

Scherpenzeel, A., and M. Das (2010) 'True longitudinal and probability-based internet panels: Evidence from the Netherlands.' In Social and Behavioral Research and the Internet: Advances in Applied Methods and Research Strategies, ed. M. Das, M.P. Ester, and L. Kaczmirek (Boca Raton: Taylor \& Francis)

Staiger, D., and J.H. Stock (1997) 'Instrumental variables regression with weak instruments.' Econometrica $65(3), 557-586$

Topel, R. (1991) 'Specific capital, mobility, and wages: Wages rise with job seniority.' Journal of Political Economy 99(1), 145-176

van Bastelaer, Alois, Georges Lemaitre, and Pascal Marianna (1997) 'The definition of part-time work for the purpose of international comparisons.' Labour Market and Social Policy Occasional Papers No. 22, OECD

Wooldridge, J.M. (2010) Econometric Analysis of Cross Section and Panel Data (Cambridge: MIT Press) 